\title{
Handling WEEE waste flows: on the effectiveness of producer responsibility in a globalizing world
}

\author{
Bastiaan C. J. Zoeteman • Harold R. Krikke • \\ Jan Venselaar
}

Received: 20 July 2009 / Accepted: 7 October 2009/Published online: 31 October 2009

(C) The Author(s) 2009. This article is published with open access at Springerlink.com

\begin{abstract}
This paper explores the present and future magnitude of global waste of electrical and electronic equipment flows, and investigates desirable changes in these flows from a sustainable development point of view. Quantitative estimates of present and future e-waste flows between global regions, generating, and processing waste are presented and their driving forces are analyzed. Global e-waste production by households exceeded an annual amount of 20 million tons in 2005. Domestic e-waste generation in China has already climbed dramatically, now equalling the amount generated in Japan. China is second in the world after the USA in landfilling and incineration of ewaste residues. Absolute volumes of recycled e-waste are largest in the EU, followed by Japan. After a period characterized by national disposal practices, a period of global low-level recovery practices has emerged. The paper analyzes exogenous factors, including legislating promoting extended producer responsibility, which are favoring as a next step regionalizing of (reverse) supply chains. Examples on a business level are discussed and critical success factors for applying regional high-level recovery are identified. The analysis shows that in the coming decades,
\end{abstract}

B. C. J. Zoeteman $(\bowtie)$

Telos, Faculty of Economics and Business Administration,

Tilburg University,

Tilburg, The Netherlands

e-mail: Zoeteman@uvt.nl

H. R. Krikke

Faculty of Economics and Business Administration,

Tilburg University,

Tilburg, The Netherlands

J. Venselaar

Avans Hogeschool University of Applied Sciences,

Tilburg, The Netherlands two options will compete on a global scale: (1) a further expansion of the present low-level recovery system of ewaste recycling, and (2) a regional approach with higher level recovery applications. The authors argue that putting businesses, more specifically, the original equipment manufacturers, instead of legislators in the driver seat, will strengthen the opportunities for high-level recovery.

Keywords WEEE - EPR - Quantified global e-waste flows . Globalization $\cdot$ EU-policy effectiveness

\section{Introduction}

Since decades, waste material and, in particular, waste of electrical and electronic equipment (WEEE) has been treated mainly as a cost factor in production. The resulting tendency was to look for the cheapest way of disposal at the nearest distance. Today, sustainable practices are legally imposed by governments with a key role for original equipment manufacturers (OEMs). We argue that policy makers insufficiently consider whether regulatory intervention is needed and, if so, at which level (global versus more regional). Moreover, firms face problems when adapting their business to meet the global sustainability criteria. This paper presents the results of a first exploration.

Multinational companies have recently been encouraged to improve waste recycling practices by government policies based on Extended Producer Responsibility (EPR), [3, 4, 30, 34, 40, 50]. EPR is defined as "a policy approach in which producers accept significant responsibility, financial and/or physical, for the treatment or disposal of products" [27, 34]. EPR policies have two distinct features: the shifting of responsibility upstream to the producer and the provision of incentives for producers 
to include environmental considerations in the design of their products, resulting in a life-cycle approach $[6,7]$. Note that OEMs (or their formal representatives) are responsible for recovery, not for collection.

For e-waste (WEEE), different national recovery systems have been in place for years, for example in Switzerland, The Netherlands, Belgium, and Sweden [41]. According to Directive 2002/96/EC of the European Union (EU), all EU member states has to have an operational End-of-Life recovery system for e-waste as of August 13, 2005 [12]. Non-EU member states like Norway, The Baltic States, and Switzerland, as well as Asian countries like South Korea, Japan, and Taiwan are adopting similar legislation [9, 40, 55]. In the USA, so-called product stewardship is becoming more accepted, and mandatory recycling is prescribed in some states $[4,10,32,33]$.

Today, many globally operating companies, such as DELL, are adopting EPR worldwide by offering free recycling services, even when not mandatorily prescribed by the regional authorities. Table 1 gives some examples on mandatory EPR in the automotive, packaging, and WEEE industry. As Table 1 shows, all countries listed apply directives with recovery quota, imposing a strong constraint on the disposition decision. The present regulations focus predominantly on waste reduction and pollution prevention by reducing waste export and increasing recycling of materials. Quotas are currently realized by achieving material recovery as well as energy recovery.

The Basel Convention of 1989 established worldwide requirements for the movement of hazardous waste and obliged the parties to minimize the generation of such waste and to ensure its environmentally sound management. The European Union transposed the Convention by Council Regulation (EEC) No 259/93 (the Waste Shipment Regulation) and, as from 1998, prohibited the export of hazardous wastes to non-Organization for Economic Co-operation and Development (OECD) countries. Different regimes apply to shipments of wastes for disposal and for recovery, as well as to hazardous and "green-listed" non-hazardous wastes, and to some special categories in-between. Shipment of hazardous wastes and of wastes destined for disposal is generally subject to notification procedures with the prior consent of all relevant authorities of dispatch, transit, and destination, while green-listed wastes, as a rule, may be shipped for recovery within the OECD like normal commercial goods and only have to be accompanied by certain information. Shipment of non-hazardous wastes to non-OECD countries depends essentially on whether the importing country accepts them and which procedures it wants to apply. Regulation No 259/93 was replaced in July 2007 by the new Regulation (EC) No 1013/2006 on shipments of waste, which streamlines the existing control procedures, incorporates recent changes of international law, and strengthens the provisions on enforcement and cooperation between member states in case of illegal shipments.

Environmental policies, as described above, prohibit simple waste disposal practices in OECD countries. But we will show that this has resulted in wider global waste streams towards cheap waste disposal sites abroad, including China, India, and West Africa. There are strong indications that, in particular outside OECD countries, sustainability objectives are not met. Profit-driven cherry picking has led to low-quality and environmentally unsound recovery, often with poor labor conditions for the workers concerned. Receiving countries generally abstract valuable components and materials from WEEE streams before burning and dumping the residues. Export abroad has been regulated by the earlier mentioned Basel Convention, which aims to reduce transboundary movements of hazardous waste to limit environmental damage. However, not all countries have joined the Basel Convention, for instance the USA has not. Other countries, such as China, are currently revising national regulation, thereby increasing quality requirements of "waste" imported for recycling.

OEMs today operate on a global scale, but recent tendencies are to organize e-waste handling on a more regional level for a number of reasons. General factors in favor of a global approach include economy of scale and low out-of-pocket costs for the exporting party. Factors favoring the regional recovery option include reduced transport costs, reduction of $\mathrm{CO} 2$ emissions, and avoiding congestion and treatment capacity problems in, for instance, Asia.

From a WEEE-flow perspective, a regional approach will also improve controllability and reduce illegal practices as well as unnecessary transportation. However, initial costs may be high due to investments and costs, and proceeds
Table 1 Recovery quota in some regions of the world for 2008 (2015)

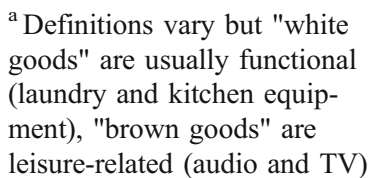

\begin{tabular}{|c|c|c|c|c|}
\hline Stream & Options & EU & Japan & Korea \\
\hline \multirow[t]{2}{*}{ Packaging } & Recovery & $60-75 \%$ & & \\
\hline & Recycling & $55-70 \%$ & & \\
\hline \multirow[t]{2}{*}{ Automotive } & Recovery & $85 \%(95 \%)$ & $30 \%(70 \%)$ & $85 \%(95 \%)$ \\
\hline & Reuse and recycling & $80 \%(85 \%)$ & & \\
\hline \multirow[t]{2}{*}{ WEEE } & White goods recovery ${ }^{\mathrm{a}}$ & $80 \%$ & $50 \%$ & $85 \%$ \\
\hline & Brown goods recovery ${ }^{a}$ & $75 \%$ & $55 \%$ & $80 \%$ \\
\hline
\end{tabular}


should be calculated over the entire product life cycle. Against the background of legal regulations implemented over the last years, the following issues are dealt with in this paper (see also Fig. 1):

a. Analysis of the gaps between the policy objectives and the actual global WEEE-flows;

b. The scale of OEMs operations and government enforcement (global/regional);

c. Case studies and surveys of successful business applications in recovery;

d. Lessons learned from cases, supported by literature and scenarios including a better span of control and a higher quality of recovery.

e. Future research.

\subsection{Objectives and approach}

This paper explores in Section 2 the magnitude of global WEEE flows and investigates desirable changes in these flows from a sustainable development point of view. We collect data on "source and sink", i.e., waste generation and reuse, on a macro level. Next, we map the different routes followed by WEEE and discuss results in Section 3. More viable and compliant alternatives, as well as their possible impacts on global WEEE streams are presented in Section 4. We present alternatives on a business level and we distil, based on a number of illustrative cases, critical success factors for applying regional high-level recovery. The studies are carried out by applying the so-called Waste and Recovery Management (WARM) method, which uses semi-structured interviews, surveys, and workshops. The alternative options are supported by extensive literature study and validated by a larger survey amongst companies in various sectors. Subsequently, we return in Section 5 to the regional and macro level, and discuss the impact at those higher geographical levels of the lessons learned. In this context, two options will compete: (1) a further expansion of the present low-level global recovery system of waste electronics recycling and (2) a regional approach with higher level recovery applications.

The role of industry (more specific the OEM) is emphasized. Putting businesses instead of legislators in the driver seat will strengthen the opportunities for small and medium-sized enterprises (SMEs). However, governments should play an active role in creating optimal conditions for the market by, e.g., setting standards in order to optimize e-waste flows globally from a sustainable development point of view.

\section{Global WEEE flows: sources, destinations, and volumes}

This section aims to provide a better insight into global WEEE flows in order to identify future risks and challenges for the global waste handling system and to provide a context to assess the potential for wider EPR application.

Although WEEE has been transported globally for decades, the quantitative characteristics are still poorly understood and monitored. This is partly due to the interest

Fig. 1 Conceptual framework for WEEE handling and research steps (a to e)

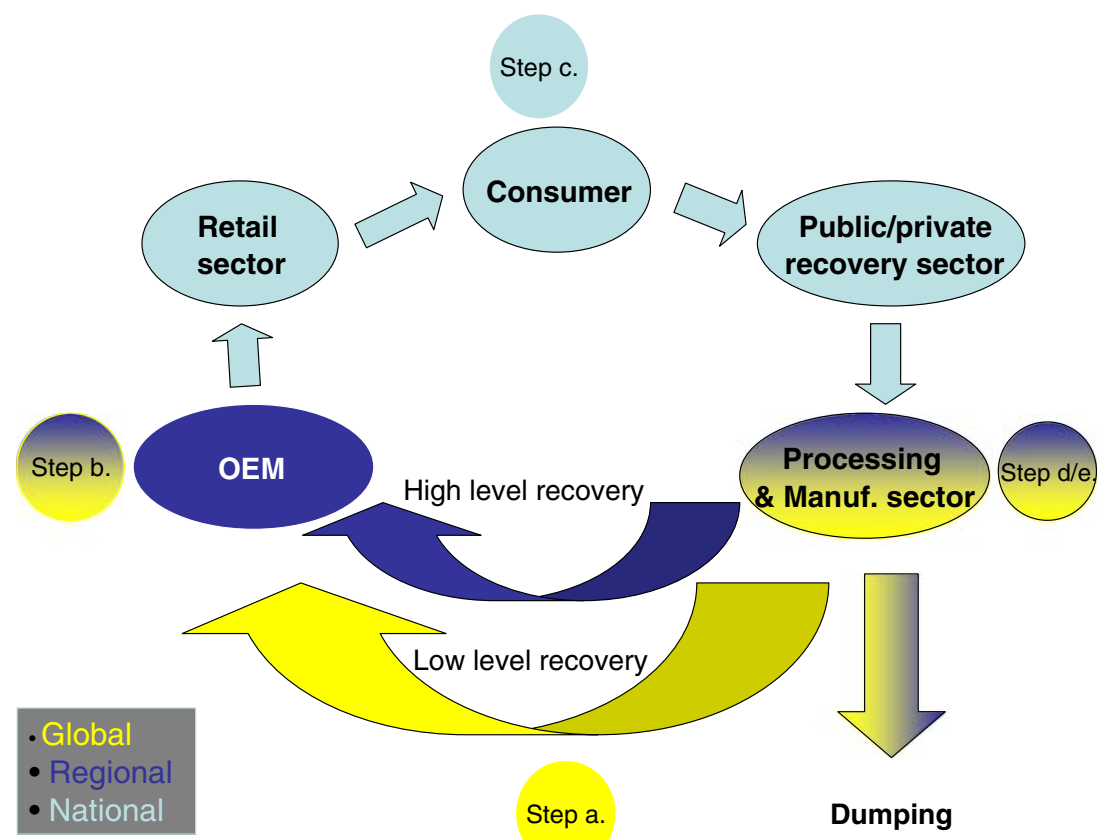


of traders in avoiding disclosure of the exact destiny of the goods they handle. New legislation, such as in the EU since 2007 and described more in detail in the next chapter, is forcing traders and waste treatment businesses to provide better information.

This section offers the best available estimates of global WEEE streams between the major regions in the global system, comprising Europe, North America, and Asia. We aim to specify waste flows for the quantitatively most important waste categories as specified in the EU WEEE Directive.

Estimating waste flows is not an easy task. After estimating waste generation, the distribution of the flow across different waste handling routes, both domestically and abroad, has to be determined on the basis of often scarce information. But even the first step of estimating waste generation is troublesome. Different methods have been proposed for e-waste generation [28, 51], such as:

1. the consumption and use method, which is based on extrapolation from the average amount of electrical equipment in a typical household;

2. the market supply method, which uses production and sales data for a certain region;

3. the old-for-new method, applied in Switzerland, which assumes that for each new appliance bought, an old one reaches its end-of-life.

As long as the use in private households is not saturated, the growth of electronic equipment use and the lifespan of this equipment have to be taken into consideration.

In this study, we have also used, when better alternatives were lacking, what one could call the "bridging indicator method". In this method, e-waste generation quota (kilogram e-waste per capita) that are typical for a region are calculated on the basis of other general indicators that are likely to correspond with e-waste generation, such as ICT investment per capita or the volume of discarded personal computers (PCs) per capita. In the future, more detailed models to predict e-waste generation will be able to provide more accurate data for regions or countries.

To arrive at estimations of international WEEE flows, amounts of waste that are processed regionally were derived using recovery and disposal options as defined by Thierry et al. [45].

\subsection{Developing a basic fact sheet for WEEE flow estimation}

Generally speaking, the availability of data and the existence of regulations are most advanced in regions such as the EU where the regulations have been in place since 2003. Evaluation of the effectiveness of the legislation is prescribed after 5 years. For this purpose, a technical report on the implementation of the WEEE directive in the EU [38] and a review study of the WEEE Directive by the United Nations University [21] provide important information that is lacking for most other regions. This necessitates making rough estimations for the other regions.

\subsubsection{Basic data requirements to estimate WEEE streams}

In view of a possible extended use in the future, it is important to set up a database that can be used for multiple purposes. This ideally incorporates the following characteristics:

- Waste characterization: the ten categories of EU WEEE directive

- Geography: country

- Periodicity: yearly, if possible more frequently

- Waste recovery process: municipal sites, in-store retailer take-back, recycle shop, producer take-back, and percentage of recovery of total WEEE supply

- Reuse in the country or region: percentage and possibly specification of type of recovery process (collective association, metal industry, and traders)

- Resulting export: if possible, specification of the receiving country and the type of waste processing

- Projections for coming years: based on past data and economic growth estimations.

Figure 2 presents a flow scheme of national WEEE generation and processing. From an overall point of view, four main options are available: (1) landfilling and incineration, the simplest form of waste handling; (2) export to low-cost regions like Africa and Asia; (3) regional material recycling, and (4) direct reuse, either domestically or abroad. We will return to this in Section 5.

The basic data specified above show that a large database is needed for detailed projections of global WEEE streams. Such a detailed approach is not yet feasible as such information is lacking at industrial sector or governmental level, and because WEEE streams are not consistently defined and monitored in different countries and regions. In addition, there are considerable problems with free riders and illegal traders, while the level of enforcement differs significantly from country to country, also within the EU. This is currently improving as a result of the new EU monitoring requirements and increased collaboration among enforcement agencies in the EU member states since 2007.

Consequently, simplifications and approximations have been made using available data as much as possible.

\subsubsection{Starting with a simplified approach}

The simplification results in a selection of four out of the ten categories of the EU WEEE Directive representing the 
Fig. 2 Flow scheme of national/ regional WEEE generation and processing

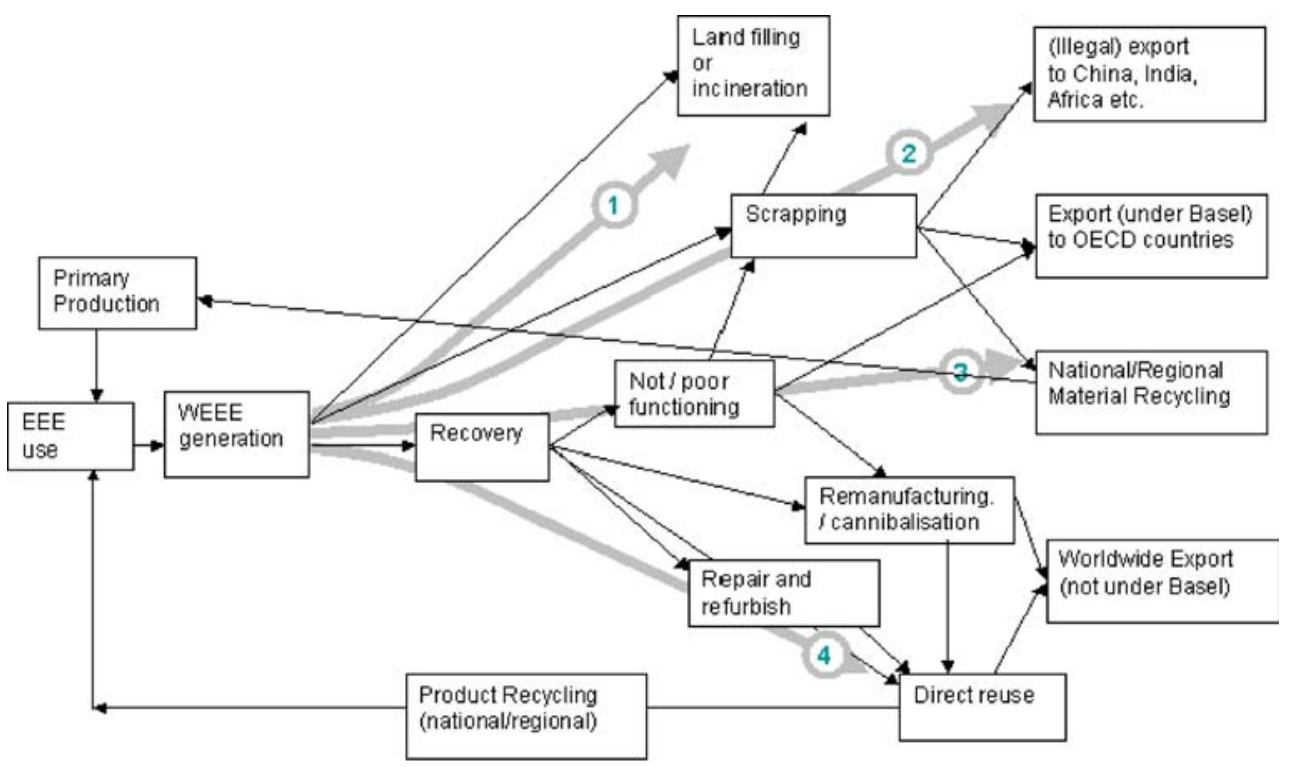

Visualizing the following stage of development: 1. do nothing; 2. Export and dump; 3 . Global material recycling and low level recovery/second hand reuse; 4. regional high ievel recovery. See $\$ 5$ for detail. largest share $(90 \%$ or more) of the volume produced. Some country-specific indicators will be used to estimate regional total waste streams.

Following this simplification, for each region estimates have been made of

- the total volume of four WEEE categories generated annually

- the amount recycled (incl. incineration) and landfilled in the, region, and

- the (resulting) amount exported/imported by the region.

Data presented in the next section are based on this format.

\subsection{Estimation of WEEE streams generated by the EU,}

North America, and Asia

Estimation of WEEE streams is not easy as direct data from nations or regions are not or to a limited extent available. Estimations, therefore, had to be based on indicator values and comparisons between countries. A detailed description of the assumptions applied is given in Appendix 1 .

The data from Appendix 1 can be summarized as presented in Table 2. This table indicates that the global WEEE production by households exceeded an annual amount of 20 million tons in 2005, as data presented do not fully take into account all nations and all streams. Still excluded are nations such as Canada and nations on the South American continent. Business-to-business streams are often not included. They are estimated to be $25 \%$ of the stream generated by households in the EU
[21]. In this paper, we focus on the household generated waste streams.

In Europe alone, the annual volume of e-waste generated by households is estimated at approximately 7 million tons per year [21, 48]. Global WEEE streams may change considerably if disposal (landfilling and incineration) in North America is reduced and exports to the developing world are increased. A total amount of 3.8 million tons (about 20\% of the global WEEE stream) was exported in 2005. Part of this stream will ultimately be landfilled in developing countries.

It is surprising how domestic e-waste generation in China has already climbed dramatically, now equalling the amount generated in Japan. China is second in the world after the USA in the landfilling and incineration of e-waste residues. Volumes of recycled e-waste are largest in the EU, followed by Japan.

Table 3 details the estimates of the WEEE flows between nations and regions. Although one might assume that the differentiation in four WEEE categories given for the export remains the same, it is in fact likely that importing countries have preferences that will increasingly be reflected in the composition of the waste streams imported. However, the present database does not allow for such a detailed analysis of the import streams. It is, therefore, assumed that no selective preferences exist in the import of WEEE categories in Asian and African countries.

According to these estimates, most WEEE export $(50 \%$ or $1.9 \mathrm{mln}$ tons) is generated in the EU, with the ports of Rotterdam, Hamburg, and Antwerp playing an important 
Table 2 Global household WEEE production, disposal, recycling, and import/export estimates ${ }^{\mathrm{a}}$ (2005)

\begin{tabular}{|c|c|c|c|c|c|}
\hline $\begin{array}{l}\text { Country/ } \\
\text { region }\end{array}$ & $\begin{array}{l}\text { Annual household } \\
\text { production in mln tons }\end{array}$ & $\begin{array}{l}\text { Landfilling, storage and } \\
\text { incineration in mln tons }\end{array}$ & $\begin{array}{l}\text { Domestic recycling } \\
\text { in mln tons }\end{array}$ & $\begin{array}{l}\text { Annual export in } \\
\text { mln tons }\end{array}$ & $\begin{array}{l}\text { Annual import in } \\
\text { mln tons }\end{array}$ \\
\hline USA & 6.6 & 5.2 & 0.13 & 1.3 & - \\
\hline EU-25 & 7 & 1.6 & $3.5^{\mathrm{c}}$ & 1.9 & - \\
\hline Japan & 3.1 & 0.6 & $1.9^{\mathrm{d}}$ & 0.62 & - \\
\hline China & 3.1 & 3.6 & 1.5 & - & 2.0 \\
\hline India & 0.36 & 0.85 & 0.36 & - & 0.85 \\
\hline $\begin{array}{l}\text { West } \\
\text { Africa }\end{array}$ & 0.05 & 0.45 & 0.17 & - & 0.57 \\
\hline Total & 20.21 & 12.3 & 7.56 & 3.82 & 3.42 \\
\hline
\end{tabular}

${ }^{a}$ From the recovered stream part that is disposed within the country/region (see estimate), part is exported to the developing world (see estimate) and the remainder is reused directly or through different types of processing like refurbishment and remanufacturing

${ }^{\mathrm{b}}$ It is assumed that $30 \%$ of the waste generated and imported is recycled in China, India, and West Africa

${ }^{\mathrm{c}}$ It is assumed that $50 \%$ of the waste generated is recycled in the EU-25

${ }^{\mathrm{d}}$ It is assumed that $60 \%$ of the waste generated is recycled

role in the export. Most of the total export flow ends up in China (53\%) and India (22\%).

\subsection{Future projections}

In Fig. 3, disposal stress $(\mathrm{kg} / \mathrm{km} 2)$, which is the sum of landfilling, storage, and incineration, divided by the land surface of the region, is plotted against the recovery effort (kg WEEE/capita). The data for 2005 and 2010 are given in Appendix 1. Figure 3 shows a high disposal stress in Japan of $1600 \mathrm{~kg} / \mathrm{km} 2$, followed by the USA at approximately $600 \mathrm{~kg} / \mathrm{km} 2$. China and Europe have similar disposal stress levels of approximately $350 \mathrm{~kg} / \mathrm{km} 2$. It is noteworthy how fast domestic household production is expected to rise in China, equalling the production of Japan in 2005 and exceeding Japan's production in 2010 by $40 \%$. Japan will probably manage to keep the disposal stress at the same level in the period $2005-2010$ by moving towards stage 4 (see Fig. 2), achieving 70\% recovery of household WEEE production.

Table 3 Global export and import per EU-WEEE category, estimations for 2005

\begin{tabular}{|c|c|c|c|c|c|}
\hline WEEE category & Other nations' import & China import & India import & W. Africa Import & Total mln tons 2005 \\
\hline EU export & 0.38 & 0.74 & 0.40 & 0.38 & 1.90 \\
\hline Cat 1 & 0.19 & 0.39 & 0.2 & 0.19 & 0.97 \\
\hline Cat 2 & 0.038 & 0.07 & 0.04 & 0.038 & 0.19 \\
\hline Cat 3 & 0.076 & 0.14 & 0.08 & 0.076 & 0.37 \\
\hline Cat 4 & 0.076 & 0.14 & 0.08 & 0.076 & 0.37 \\
\hline USA export & & 0.91 & 0.26 & 0.13 & 1.30 \\
\hline Cat 1 & & 0.55 & 0.16 & 0.08 & 0.78 \\
\hline Cat 2 & & 0.073 & 0.021 & 0.01 & 0.1 \\
\hline Cat 3 & & 0.146 & 0.042 & 0.021 & 0.21 \\
\hline Cat 4 & & 0.168 & 0.042 & 0.021 & 0.21 \\
\hline Japan export & & 0.38 & 0.18 & 0.06 & 0.62 \\
\hline Cat 1 & & 0.21 & 0.1 & 0.03 & 0.34 \\
\hline Cat 2 & & 0.032 & 0.017 & 0.005 & 0.054 \\
\hline Cat 3 & & 0.066 & 0.033 & 0.011 & 0.11 \\
\hline Cat 4 & & 0.066 & 0.033 & 0.011 & 0.11 \\
\hline Total export/import & 0.38 & 2.03 & 0.84 & 0.57 & 3,82 \\
\hline Cat 1 & 0.19 & 1.15 & 0.46 & 0.3 & 2.1 \\
\hline Cat 2 & 0.038 & 0.18 & 0.078 & 0.053 & 0.35 \\
\hline Cat 3 & 0.076 & 0.35 & 0.16 & 0.11 & 0.69 \\
\hline Cat 4 & 0.076 & 0.37 & 0.16 & 0.11 & 0.69 \\
\hline
\end{tabular}


Fig. 3 WEEE disposal stress and recovery effort of regions worldwide estimates 2005/2010

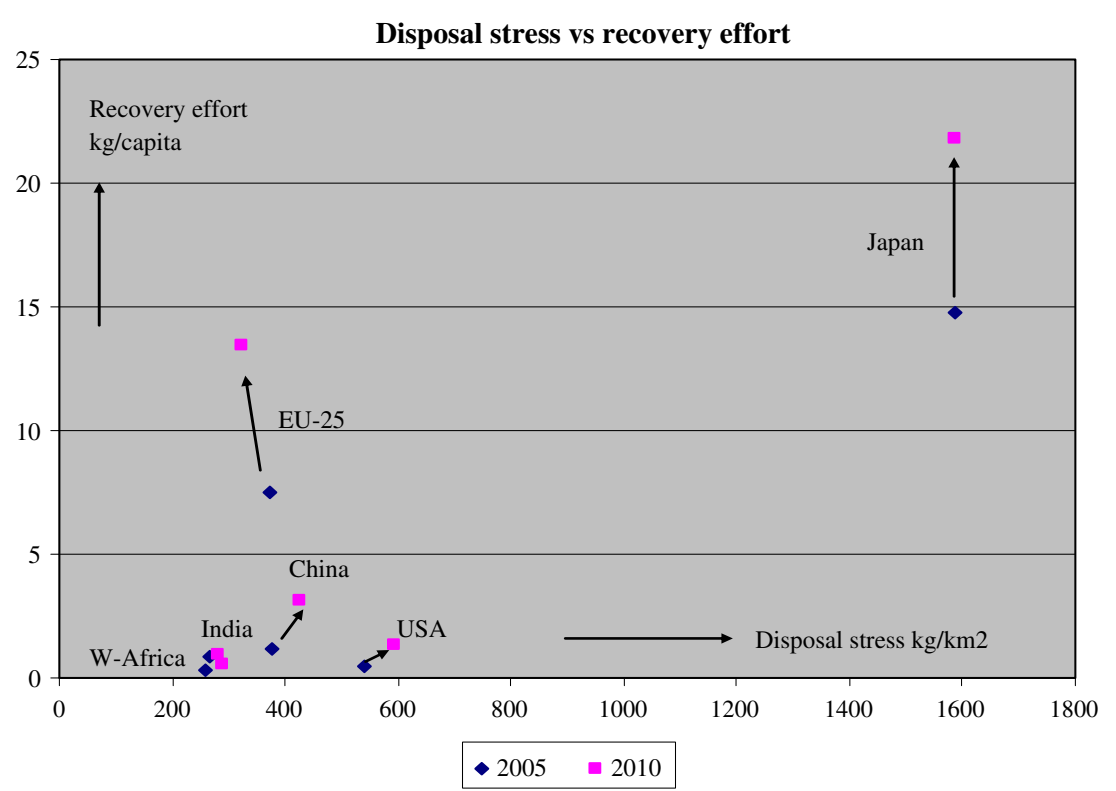

The EU-25 is the first region that will probably reduce disposal stress in this period by strongly improving its recovery effort from $50 \%$ to $66 \%$. Besides disposal stress, the strong policies to promote sustainable development are probably a factor in explaining the expected doubling of the recovery performance in the EU between 2005 and 2010. The USA is lagging far behind, reflecting the already described stage 1 position of this country.

Although recovery efforts are likely to increase, the main recovery option for the near future remains global material recycling. The goal of a sustainable society that is less material-intensive still seems far away, when the WEEE production forecasts are considered.

Figure 4 gives an overview which shows the impact of GDP on WEEE production volumes. Although China's WEEE production is still relatively low in terms of $\mathrm{kg} /$ capita, the absolute quantities are large. China is already the third biggest WEEE producer in the world and will probably become the biggest around 2020. All countries and regions still show a fast increase in e-waste production, a trend which is not likely to be reversed in the foreseeable future.

\section{Analysis of global e-waste flows}

The data presented give cause for some reflection and interpretation. First, several authors $[17,20,26]$ argue that the EU policies based on EPR may lead to low quality and environmentally unsound solutions. As part of the "openloop" problem, illegal exports remain a problem, while the reuse and transportation add to the energy use. Our data confirm that EU directives do indeed stimulate recovery, but mostly via alternative applications in what is euphe- mistically described as "cascade markets". Moreover, the collectively organized systems make that the incentives for individual OEMs to apply eco-design are limited. We can see that, although profitable for some actors in the playing field, there is still an overall deficit for many recyclers. Apart from tradable commodities, such as scrap and waste paper, quality and, hence, economic proceeds are often low. Waste reduction is not achieved, given the ever-increasing volumes presented in Table 2 and Fig. 4.

Moreover, disassembly and recycling in receiving countries often takes place under poor working conditions [44]. The EU Directive for Transboundary Movement of Waste Materials may hinder, but not prevent export as economic forces often win from than enforcement.

Waste export mostly is the result not just of low labor costs and dumping, but of the need in industrially developing countries such as China and India for materials. They recognize the value of streams that are seen as just waste by the developed countries. On the other hand, growing economic prosperity in Asia will make this region a major WEEE producer in the future, as Table 2 and Fig. 4 show.

Although it is difficult to trace origins and destinations of all flows, it is fair to assume that large parts of WEEE travel long distances. Globalization certainly has its merits but also increases energy use and, hence, $\mathrm{CO} 2$ emissions. Global is not green [31]. Moreover, as environment is becoming an economical factor, global sourcing is being reconsidered. Rubin and Tal [37] show how steel industry is already regionalising on a large scale, where Mexico has gained large portions of the USA market, and Chinese exports have dropped by $20 \%$. (Out-) sourcing strategies have also led to complex supply chain networks, with different locations for different activities. 
Fig. 4 WEEE production of regions in the world as a function of GDP/capita
E-waste production versus GDP/capita

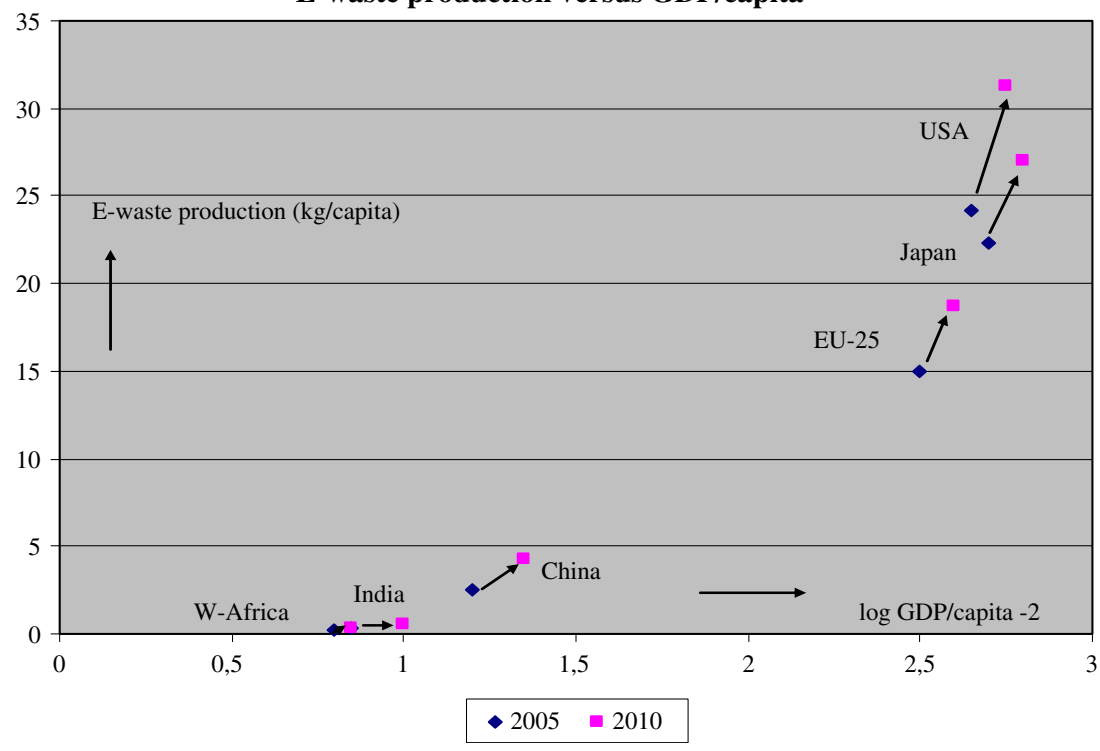

Illegal WEEE trading will remain common, given its profitability. This will probably result in a redirection of the WEEE streams to those countries where requirements are lowest (race-to-the-bottom effect). For this reason, we expect West Africa to be an increasingly popular destination among illegal exporters from the EU and Japan, and still legal exporters from the USA. In the second place, certain areas in Eastern Europe are still used as dumping sites. As a counterforce, governments are tightening the enforcement which will reduce illegal trade in this region $[49]^{1}$. Additional measures to help prevent illegal trade will be necessary, however, such as a guarantee from the remanufacturer/exporter to take back discarded equipment. Regionalizing recovery leads to less transportation and to recovery close to the market, which increases control for the OEM and government enforcement agencies. Governments can encourage business intentions in this direction through legal and financial incentives, though this is more common in the EU than in North America where a free market approach dominates.

The economic principle underlying the situation at the end of the first decade of the twenty-first century is that out-of-pocket costs are minimized and that the materials recovered can compete (at least in price) with virgin materials. Although there is a lively trade in recyclable materials, proceeds for the OEM are low and recyclers may charge traders and logistics service providers. Costs are directly passed on to the customer either as a non-visible part of the cost price or as an explicit removal surcharge. In addition to economic disadvantages, "open loop" recycling is hard to enforce and to monitor for governments.

\footnotetext{
${ }^{1}$ VROM inspectie: Inspectorate of the Dutch Ministry of Housing, Spatial Planning and Environment
}

Discarded products are also quite an undervalued source of parts for maintenance and the assembly of new products, however. To this end, higher-level recovery options should be applied and a life cycle perspective should be developed [24].

Referring to the four options in Fig. 2, the world as a whole is at the end of the first decade of this century in a transition from stage 1 to 2, with EPR pushing for development to stage 3 . To achieve sustainability that is profitable, one has to move to more high-level recovery options, hence downward in Fig. 2. How to move towards stage 4 is discussed in the following section. The potential impact of the latter transition on global WEEE streams will subsequently be assessed.

It is important to note that recovery denotes all forms of recuperation for reuse. Basically, six recovery options are given at a conceptual level, namely: (1) direct reuse, (2) repair, (3) refurbishment, (4) remanufacturing, (5) cannibalization, and (6) recycling (adapted from [45]). Direct reuse concerns checking and cleaning activities, e.g., the refill of toner cartridges; repair restores a product to working order; and refurbishing entails an upgrade and replacement of some critical modules/parts. All these options concern product reuse, which is not included in the EU WEEE directive quota, but is seen as trading flows under the EU Directive for Transboundary Movement of Waste Materials. Remanufacturing produces as good as new products partly from old components and materials; cannibalization involves the selective retrieval of components and modules (others are scrapped) mainly for spares applications; and material recycling is seen as the "lowest" form of recovery. There are many publications proving that higher quality recovery (read remanufacturing) should be encouraged both from an environmental and a viability 
point of view. In the next section, we discuss this and present some illustrative options.

\section{Options for a different approach}

The challenge from a sustainable development point of view is to develop closed-loop supply chains, i.e., maximum recovery for reuse in the original supply chain, or some cascade segments also under control of the OEM [16]. Typical recovery options include remanufacturing, cannibalization (spare parts), and refurbishment.

\subsection{Encouraging high-level recovery on a regional basis}

High-level recovery aims to substitute new production in order to be economically viable and ecologically sound. Recovery often proofs to be cheaper than new production, as it avoids the use of virgin material, often saves energy resources, and avoids other costs which are invested in the recovered products.

\subsubsection{Economic viability}

Direct reuse, refurbishing, parts cannibalization, and remanufacturing usually recover more value than just the materials, as happening in recycling. It is economically profitable because when leaving equipment and parts as much as possible in their original form, the total value present in discarded products is used. Labor invested, logistics, and many other organizational and administrative costs make up the price of a product, in addition to the costs of the materials used. Materials often form only a small part of the total cost. Studies $[14,15,29]$ indicate that up to $90 \%$ of the total original costs are "recuperated" during reuse, which is sometimes felt as "counter-intuitive". One assumes that the extra work for collecting, disassembling, controlling, cleaning, repairing, etc. must be prohibitive because of high costs of labor, whereas new production elsewhere is cheap. However, recovery for high-level reuse entails far less work than new production starting from scratch. Much value is locked up in the product, including labor, material and energy costs, and quality control costs, etc., which can be reclaimed.

Remanufacturing can be as efficient as virgin production and assembly, if not better. Practice proves that even cheap $(€ 15 /$ piece $)$ and somewhat complicated electrical motors can be refurbished and adapted for $50 \%$ of the new price [5]. For parts with a higher value or a simpler construction, this ratio becomes even more advantageous (cannibalization). So if other costs, e.g., for collection and disassembly can be kept low, reuse is profitable for many products and companies. If done on a much larger scale than presently practiced, it would effectively control the various streams of discarded products in a much more economical way. Last but not least, quality standards also in Asia are expected to rise ( $\mathrm{HbR}$, personal communication).

The viability of high-level closed-loop recovery was proven in our program with SMEs (Appendix 2), but is also mentioned in other studies [13, 15, 35, 36, 42, 46]. Products involved include office photocopiers, vending machines, electrical motors and compressors, industrial food processing equipment, computer and telecom equipment, airconditioning units, and truck engines. In the USA, it is estimated that a total of 73,000 firms are involved in some form of remanufacturing (as service to OEMs) in 46 product areas, employing 480,000 people and with company sales around $\$ 53$ billion [14]. In the UK, the remanufacturing industry employs more than 50,000 people with company turnover of around $£ 5$ billion [15].

\subsubsection{Ecological soundness}

There is clear evidence from the studies mentioned that high-level closed-loop recovery is also more environmentally friendly then most present practices, as energy efficiency improves compared to virgin production [18, 25]. Kerr and Ryan [23] indicate that remanufacturing can reduce resource consumption and waste generation during production, e.g., over the life cycle of a photocopier this reduction can reach up to a factor of 3 , with greatest reductions if a product is designed for disassembly and remanufacturing. The advantage lies in the fact that not just materials are recovered but that energy is saved as well, thus cutting $\mathrm{CO}_{2}$ emissions. It is estimated that remanufacturing only needs $15 \%$ of the energy compared to manufacturing from scratch [14]. Recovery of materials alone generally is still less energy-intensive than primary production $[2,26]$. Wright et al. [52] estimate the energy benefits for secondary metal production for aluminum at $94 \%$, for copper at $75 \%$, for lead at $70 \%$, and for steel at $40 \%$. Energy consumption and, in particular, the environmental impact of the scrapping, separation, and treatment of the discarded equipment is still extensive and the costs are, therefore, high [19, 21]. Contrary to recycling, high-level recovery also recovers the energy used during the manufacture of all components and subcomponents, of the assembly process and of much of the transport required. Moreover, part of the materials is irretrievably lost during processing, which is not the case for reuse. Moreover, involvement of the OEM and other supply chain member guarantees quality standards and may help to prevent illegal exports, as discussed earlier [26]. Application of high-level recovery in many cases also reduces the eco-footprint [18]. Substitution, the saving of resources by using recovered items, materials, and energy, thus, replacing virgin produc- 
tion processes, is an important cause of this reduced footprint. In general, substitution is favorable as it saves energy, materials, and costs. To achieve this effect, the reverse logistics channel must be competitive with the new production of components and materials.

\subsubsection{Transport issues}

The exodus of the Western make industry to the Far East and Central America has also led to, amongst other things, increased distances and complicating supply and communication lines. To some degree, however, the global outsourcing trend since 2000 may backfire due to the competition for raw materials, increasing pollution problems in the Far East and international shipping constraints. A capacity shortage at the world's major hubs causes delays, a lack of effective shipping capacity and, hence, higher tariffs.

Regional recovery is complementary to this and additionally reduces risk and $\mathrm{CO} 2$ emissions as well as cost of (transport) energy. Eastern Europe, Mexico, Brazil, Ukraine, China, and some of the more advanced African countries may prove to be factories of the region. Remanufacturing fosters local sourcing, where suppliers are often at the OEMs site. However, a good market in Asia for recyclable non-hazardous commodities will probably remain.

\subsection{Overcoming obstacles to high-level recovery} at business level by applying the WARM approach

Regional remanufacturing is, in our opinion, still insufficiently recognized as a feasible proposition. Main obstacles are, e.g., the envisaged complexity of the reverse logistics, doubts about the quality of recovered parts, and changes that need to be made in design and set-up of production facilities. Better and more detailed insight into the actual cost structure of products is required, and companies need to adapt the way products are marketed. Nevertheless, new regulations such as the EU WEEE Directive and the growing scarcity of raw materials are prompting OEMs to reconsider their position in this matter. Besides, remanufacturing offers new business and job opportunities and can stimulate local and regional economies, as demonstrated in the USA. Authorities can promote it as an alternative for the materials recycling route commonly chosen. As SMEs miss the capabilities and information to introduce highlevel recovery, they need structural support. Our program, the so-called "WARM approach" (which stands for Waste and Recovery Management), described in Appendix 2, aims to develop methods and instruments that can help SMEs.

This study was split into two major groups of companies: one group dealing with fairly advanced companies and a second group with less advanced companies. In the first group, in-depth semi-structured interviews were combined with a "pressure cooker" workshop to identify critical success factors for high-level recovery. The examples below ${ }^{2}$ show that remanufacturing, recovery, and refurbishment are also viable and highly profitable propositions. All companies are SMEs, which are active in limited geographical areas. The second group of less advanced companies was surveyed to research the wider potential of reuse in order to validate the findings.

The first case, a typical example of refurbishing, is Ecotax Security Technology at Willemstad (The Netherlands). It sells fences with electronic touch detection and protection systems. Fence parts and security equipment frames, used for instance on temporary building sites, are overhauled completely with minor parts replaced, but reassembled in the original form and function. Practically everything is reused in some form. Overall production costs are considerably less and, at the same time, new jobs are created through the recovery activities, while new markets for lower-priced systems are developing.

An example of remanufacturing is Sweere Food Processing Equipment BV at Zevenbergen (The Netherlands). It sells crop-harvesting equipment. It imports new equipment from the USA, but also remanufactures discarded equipment, usually 10 years old or more. Collected equipment originates from all over Europe. The equipment is disassembled to main parts that are cleaned, controlled, and, if necessary, repaired and modified to make them suitable for reuse in new equipment. Remanufactured equipment is sold at a price of $50 \%$ to $60 \%$ of new equipment to customers who cannot afford to buy new versions. In this way, they have expanded their market substantially. The original manufacturer fully cooperates because this benefits his companies too, e.g., by supplying the spare parts.

Cannibalizing concerns the use of recovered modules and parts for repairs and replacements, if necessary after refurbishment, in still-functioning equipment. Coffee 3 at Udenhout (The Netherlands) is a typical example. It supplies coffee dispensing appliances for office use. Returned appliances are disassembled and parts are checked and cleaned. When servicing and repairing, customers are offered the choice between new parts or refurbished parts as a cheaper alternative. The company is planning to offer equipment made mostly of reused parts and modules, leading to whole-scale remanufacturing. It would open a new market with customers that cannot afford or do not need new and latest model equipment.

\footnotetext{
${ }^{2}$ The experience and cases described are the result of our research program described in Appendix 1. It is concerned with case-based research and involved interviews with managers of companies and pilot projects to identify options and constraints in introducing reuse.
} 
These cases illustrate an often-seen sequence of events. Companies start with refurbished parts to service equipment. Once this activity grows and proves to be profitable, actual remanufacturing becomes attractive.

\subsection{Lessons learned}

The introduction of high-level recovery in, e.g., SMEs can be realized in 2 or 3 years time. As is illustrated with the cases presented the concept is applicable to a wide set of product-groups, different strategies for reuse and remanufacturing are relevant for producers and suppliers and for different phases of development.

In most cases, profit is clearly the prime incentive and environmental benefits are a spin-off. The value recovered is compared with the costs of collecting, dissembling, refurbishment, and control. Furthermore, production costs can be reduced because production lines profit more and longer from existing and proven designs, set-ups, and equipment parts. Time involved in re-designs and production lines also proves to be shorter.

Closed-loop recovery stimulates a remodeling of customer relations, with novel market strategies and advantages for customers and producers. Concepts like product lease with extended customer services, such as fast replacement of older equipment, are common now in the copier business. This benefits overall quality as well since returned products provide a lot of information on products' weak spots and design flaws. Designs and performance can consequently be optimized. The main points of attention, which are at the core of the WARM approach, include the following:

- A reliable and steady stream of returned equipment for a sufficient stock of parts. The volume of equipment and products that will be involved in high-level recovery is uncertain. Reverse logistics to handle this is an evolving business field attracting many companies [45]. It will take some years before a sufficiently large and reliable reverse stream of products exists. It depends of course on the average lifetime of a product. A producer can to a certain extent influence this when lease is involved and through trade-in by stimulating the exchange of older products for new ones.

- The need to measure and control the condition, wear, and remaining lifespan of equipment and parts to guarantee sufficient quality for reuse. Visual control and simple tests often suffice. For more complex structures such as electronic parts, particular methods for testing are required and are being developed [8]. Depending on the sturdiness of design and materials applied, the history of used equipment and parts can be categorized as "as good as new" or as lower grade. On the basis of the outcome, the corresponding quality and lifetime can be guaranteed.

- Rapid changes in technology and "fashion" can make perfectly functioning parts unfit for reuse. This often concerns only specific parts, e.g., electronics or the visible outer layer.

- Customers and sales departments may fear lower quality or reputation damage. In reality, high-level recovery is incorporated already in many production processes without any adverse consequences. Many appreciate and even require the reduced costs and the "sustainability aura" provided by remanufacturing.

- The relationship with suppliers of original equipment and parts may be jeopardized, as they may fear losing business. Looking for mutual benefits helps to overcome these fears.

- Products with high obsolescence rates (such as computers) have problems to create closed loops, because new production cannot be substituted by recovery.

- Material recycling requires huge economies of scale to be profitable. Its open-loop markets are, therefore, globally oriented. High-level recovery requires less scale but higher responsiveness and, therefore, suits regional sourcing. In combination with ongoing technology developments, the quality, sustainability, and viability of recovery is rapidly improving.

- Design for recovery enables a whole set of recovery options, ranging from remanufacturing to material recycling and energy recovery. Product modularity and commonality also increase the potential for highlevel recovery options. Moreover, regional high-level recovery options will make it easier to identify and remove hazardous materials close to the source of the waste.

- Life cycle costing. Initial costs are high due to, for example, product design changes and the set up of collection systems Revenues come later in the product life cycle. Accounting systems are not geared for this and have to be adapted. In fact, a more long-term focus on costs and revenues is needed.

In conclusion, there are several critical success factors for achieving high-level regional recovery. All success factors are in the hands of companies. A major consequence of our analysis is that industry should take the lead, encouraged by standards and other facilitating actions from governments such as removing unnecessary legal constraints.

\subsection{Wider impact}

Table 4 displays the benefits when applying high-level closed-loop recovery using indicators similar to those 
Table 4 Different reuse strategies found in practice with economic and environmental impact

\begin{tabular}{|c|c|c|c|c|c|}
\hline Equipment type & $\begin{array}{l}\text { Existing market, reuse in } \\
\text { new equipment, for overall } \\
\text { cost, materials, and energy } \\
\text { reduction }\end{array}$ & $\begin{array}{l}\text { Renew market, cascade options, } \\
\text { as alternative for own "new" } \\
\text { products reducing energy and } \\
\text { material use }\end{array}$ & $\begin{array}{l}\text { Low-priced export } \\
\text { leading to increased } \\
\text { waste and energy use } \\
\text { and more profits }\end{array}$ & $\begin{array}{l}\text { Service for } \\
\text { customers, lower } \\
\text { priced replacement } \\
\text { for faulty equipment }\end{array}$ & $\begin{array}{l}\text { Lower } \\
\text { prized } \\
\text { spare } \\
\text { parts }\end{array}$ \\
\hline $\begin{array}{l}\text { Large office } \\
\text { equipment }\end{array}$ & ++ & + & & & + \\
\hline $\begin{array}{l}\text { Computers, } \\
\text { small } \\
\text { printers etc. }\end{array}$ & & & $+/-$ & + & \\
\hline $\begin{array}{l}\text { Vending } \\
\text { machines }\end{array}$ & ++ & & & & \\
\hline $\begin{array}{c}\text { Agricultural } \\
\text { equipment }\end{array}$ & & ++ & $+/-$ & & + \\
\hline $\begin{array}{l}\text { Coffee and } \\
\text { drinks } \\
\text { dispensing } \\
\text { machines }\end{array}$ & & + & & + & ++ \\
\hline $\begin{array}{l}\text { Medical } \\
\text { equipment }\end{array}$ & + & + & & + & \\
\hline
\end{tabular}

defined earlier in Section 4.2. It is based on a larger survey of companies in the same business sector as described earlier and three additional branches of industry. In most cases, synergy exists between economic and ecological goals, but for low-priced exports, it proves difficult. Proceeds are good, but the environment is not well-off. This can be explained by the fact that most of the exports are internationally and even globally oriented, and are not connecting to the urge to regionalize.

A broader sustainability lesson, therefore, is that closedloop recovery systems clearly favor regional approaches over global ones. The companies involved in our research program contracted often the refurbishment of parts and modules out to specialist firms to reduce costs. Short distances which foster direct contact and cooperation is seen as crucial to reach high quality in the remanufacturing process. OEMs expect to better control their responsibilities and ambitions in this way. This clearly stimulates regional economics as a growing number of companies enter this market.

\subsection{Global scenarios}

In summary, we propose the following four global scenarios, as illustrated in Fig. 5 to describe past and possible future developments:

1. Local dumping: the result of no active policy is local disposal (landfill and incineration). This scenario is the first development stage which, unfortunately, still applies to large parts of the world, e.g., parts of the USA. Once local and regional landfills are full, developed countries will be looking for cheap ways to get rid of their waste and in doing so, may move to the next stage.
2. Export and dump: export and particularly dumping in developing countries is a logical follow-up from development stage 1 as legal constraints have to be met. Smart traders will make money two ways, charging the local disposer on the one hand and selling some valuable recyclables abroad. What is left finds its way to the cheapest country. West Africa may become the center of this flow in the future. The geographical scale, thus, expands to the global level and recovery quality remains low.

3. Global low-level recovery: commodity trading markets are resulting from the previous development stage, especially in Asia. The open-loop development is partly the result of EPR-based legislation and partly due to a strong demand for materials in the Far East. This stage is also global and the level of recovery of valuable component or materials improves by applying open-

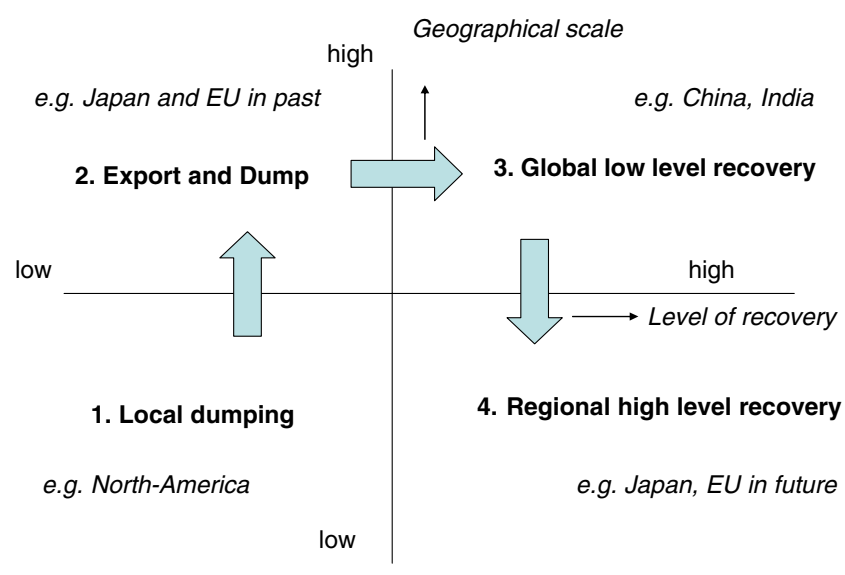

Fig. 5 Global scenarios in sustainable WEEE recovery and examples of regions representing such scenarios 
loop recycling which is not yet achieving high-level closed-loop recovery.

4. Regional high-level recovery: component- and modulebased reuse is achieved in closed-loop developments using regional high-level recovery options, of which the first examples can be found in the EU and Japan. The business cases presented earlier illustrate this concept. Businesses take the initiative using the critical success factors mentioned earlier as steering variables.

Development stages towards a more sustainable situation in the future can be defined using two critical dimensions: geographical scale and level of recovery. These two characteristics determine whether or not e-waste returns are processed in the region of origin and if reuse and recycling take place in the original supply chain (high-level recovery) or some alternative supply chain (low-level recovery). Many companies are still in stage 1 or 2 , but Basel Convention regulation and its follow-up are rapidly promoting stage 3 . EPR-based regulations recently advocate stage 4 which allows a better sustainability performance $[18,25]$. As discussed before, high-level recovery tends to favor markets on the same continent due to low labor intensity, low energy and materials intensity, and the lack of this type of recovery option in the Asian markets which are more geared towards material recycling.

National regulations and recovery infrastructures, however, concentrate on a recycling route requiring cooperation by specific industry sectors. This hinders changing remanufacturing routes, which have to be (re)invented for each company. Some regulations seem to block this logical and more profitable route because sectoral policy considerations were dominant during their conception. An example is the EU Restriction of the Use of Certain Hazardous Substances in Electrical and Electronic Equipment Directive which discourages the reuse of parts containing hazardous substances (lead for instance), even though these are not released during reuse. Achieving a better alignment with the goals of the WEEE Directive by the European Commission is desirable. A more positive incentive can be given through, e.g., certification programs allowing certified companies less strict enforcement regimes. The government can contribute furthermore, e.g., by setting long-term recovery goals, as well as by softer instruments like eco-labeling.

\section{Conclusions and outlook}

This paper has discussed global e-waste streams and driving forces, such as EU-policy and resulting legislation/regulation which will influence future developments. The findings include:

1. The volume of household WEEE streams, estimated for 2005 at 20 million tons globally, will continue to increase strongly if no additional measures are taken. Low growth rates in the EU and Japan will be rather the exception. Annual export/import flows between regions are estimated for 2005 at 3.8 million tons, creating serious environmental and health problems at the locations receiving these wastes.

2. Local disposal of WEEE, described as development stage 1 , is still a major practice (12 million tons in 2005), but in

Fig. 6 WARM framework

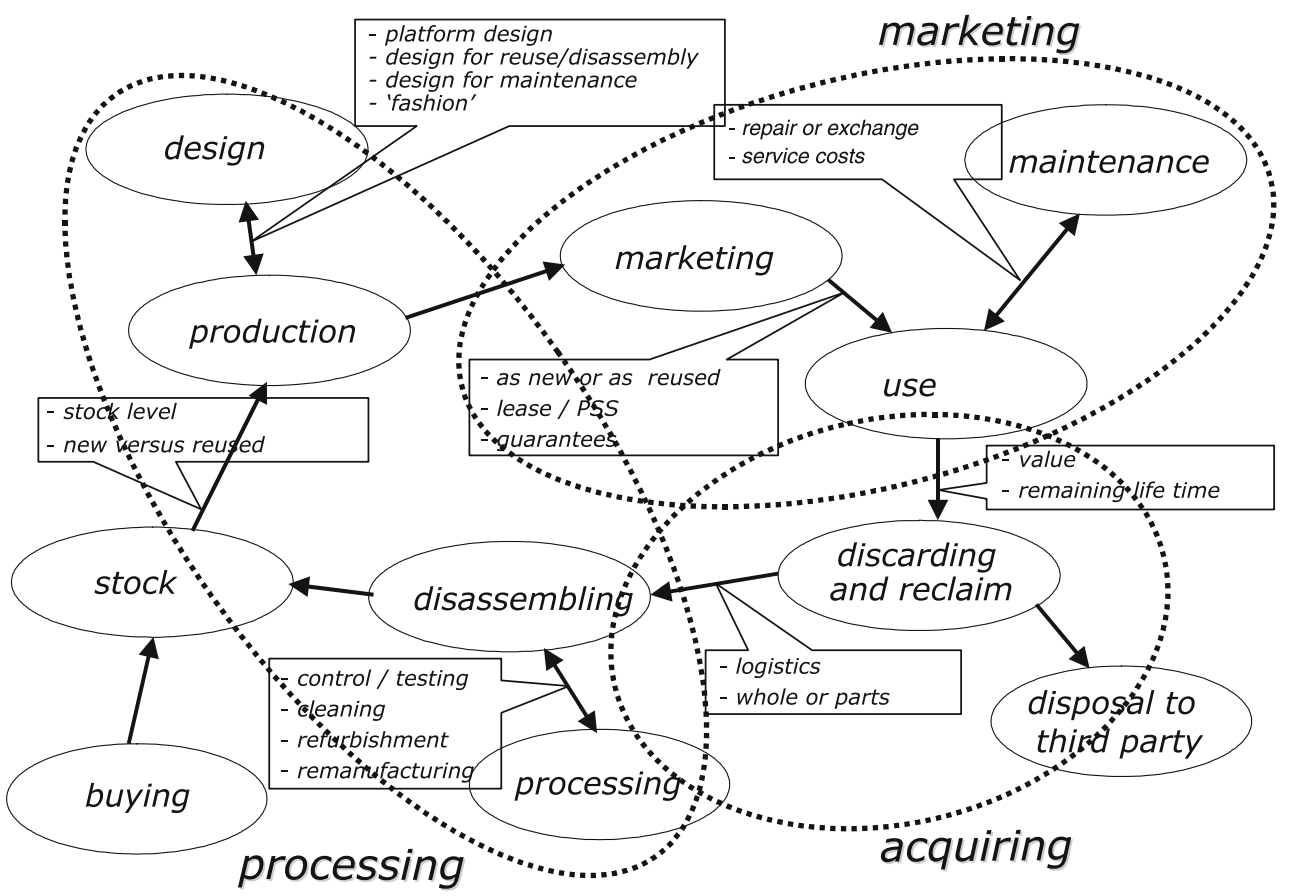




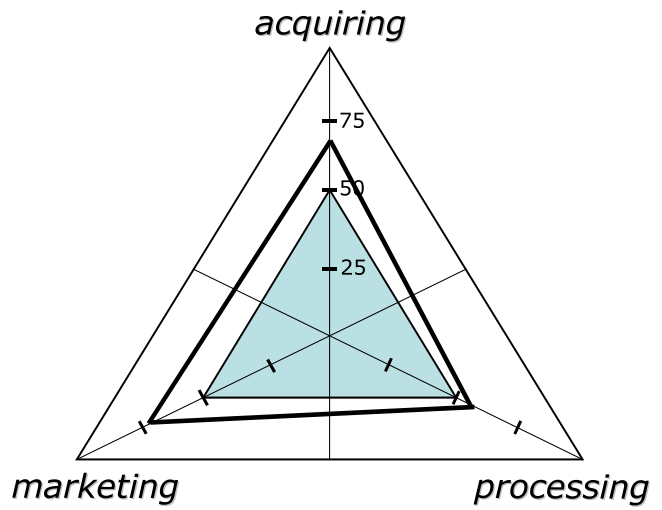

Fig. 7 A simple diagram to show constraints or opportunities for reuse

certain regions of the world like North America a "local disposal" policy may soon be followed by development stage 2, "export and dump, which has also been practiced in the past by Japan and the EU. West Africa is a receiving region at risk in this respect.

3. Led by Japan and the EU, global low-level recovery, development stage 3, mainly aiming at material recycling in Asia, is emerging.

4. Although global material recycling, as enforced by government regulations in international frameworks, is a more sustainable option than exporting and dumping, it is an open-loop system avoiding the more sustainable optimization that can be achieved within the original supply chain.

5. This analysis shows the importance and practicability of closed-loop high-level recovery options applied at regional scales (proposed as development stage 4). The challenge facing the business community, the OEM, is to take the lead in taking further steps toward achieving truly sustainable solutions. The WARM approach, presented in this paper, illustrates the gains such an approach can provide at the individual company level.

6. Critical success factors have been identified to achieve high-level recovery on a regional basis, giving a key role to industry. The business cases show that development stage 4 is achievable leading both to economic profits, and better eco-footprints. Several external forces, such as rising transport and material cost will probably favor stage 4 in the future. However, reaching this stage or even passing stage 3 is no trivial matter. Industry has to take the initiative, but governments should facilitate by creating favorable conditions.

7. The government contribution may include long-term recovery goals, standard setting, removal of inconsistencies in regulations, promotion and gratification of certification, and eco-labeling.

This paper is a first modest step in showing the need and potential for high-level recovery practices on a regional basis.
For future research, it will be important to better quantify global WEEE streams using more accurate e-waste generation data. Furthermore, it is needed to periodically update the overview of domestic and international e-waste flows and forecasts by including new policy decisions and private sector initiatives. This can show where and how fast developments from stages 1 till 4 are taking place. Such insights may help to indicate companies and governments which additional instruments and steps can be used to improve sustainable development on a local, regional, and global level.

Acknowledgment This research is partially sponsored by Transumo ECO project, proj. no. GL05022b.

Open Access This article is distributed under the terms of the Creative Commons Attribution Noncommercial License which permits any noncommercial use, distribution, and reproduction in any medium, provided the original author(s) and source are credited.

\section{Appendix 1. Estimation of actual WEEE streams generated by the EU, North America, and Asia}

Estimations for the year 2005

$\mathrm{EU}$

Generated volume of WEEE

The EU JRC/IPTS report of Savage et al. [38] states that electro-scrap is the fastest growing waste stream, growing at a rate of $3-5 \%$ per year. Each EU-15 citizen is thought to currently produce (2005) 17-20 kg of e-waste per year. Others have estimated a range of $14-20 \mathrm{~kg}$ per capita [11]. Some $90 \%$ of this waste is still landfilled, incinerated, or recovered without any pre-treatment. The key aims of the EU legislation are to seriously reduce landfilling, improve take-back systems, improve product design, and achieve targets for recovery $(75-80 \%)$, reuse, and recycling (50$75 \%$ ) of different classes of WEEE. By the end of 2006, the member states of the EU were supposed to collect WEEE separately at a yearly rate of at least $4 \mathrm{~kg}$ /inhabitant. A more stringent target will be set later. Member states must inform the Commission on their results over 2005 and 2006 using a standard reporting format.

Detailed data show considerable differences between member states, of which Germany, UK, France, and Italy are the largest WEEE producers and former Eastern European countries have much lower amounts of WEEE. The figure of 17-20 kg/inhabitant per year mentioned above may be too high, as the WEEE-Forum ${ }^{3}$ calculates for the collected WEEE by the non-profit collective take-back systems of members of the forum for full operative collection systems $10 \mathrm{~kg}$ /inhabitant per year. This figure

\footnotetext{
${ }^{3}$ www.weee-forum.org
} 
applies to 16 systems in 12 relatively small EU member states, however. Moreover, the collection systems do not achieve $100 \%$ recovery. A value of $15 \mathrm{~kg} /$ inhabitant/year for the total of $457 \mathrm{mln}$ inhabitants of the EU is a reasonable preliminary approximation. Only after the reporting over 2005 and 2006 to the Commission is available, more accurate estimates can be made.

The present estimations result in a total estimated yearly supply of WEEE in the EU of: $457,000,000$ (inh.) $\times 0.015$ tons $(15 \mathrm{~kg} / \mathrm{inh}$. $)=7,005,000$ tons WEEE in 2005 ; of which roughly speaking:

$50 \%$ is large household appliances (fridges and washing machines; $7.5 \mathrm{~kg} / \mathrm{inh}$.)

$10 \%$ is small household appliances (vacuum cleaners and toasters; $1.5 \mathrm{~kg} / \mathrm{inh}$.)

$20 \%$ is office and communication waste (computers and cell phones; $3.0 \mathrm{~kg} / \mathrm{inh}$.)

$20 \%$ is entertainment electronics (radios, TVs, and stereos; $3.0 \mathrm{~kg} / \mathrm{inh}$.)

Amount recycled and landfilled in the region

Over the coming years, recycling and remanufacturing are going to be important obligations to EU members states, whereby high percentages of the total WEEE stream of $50 \%$ and more can be achieved, as demonstrated by leading countries in Europe such as Switzerland, Norway, UK, Belgium, and the Netherlands. E-waste recycling in Switzerland amounted to $11 \mathrm{~kg} / \mathrm{capita}$ in 2004 [18]. However, presently, at least $15-20 \%$ of the WEEE streams is not collected and treated as prescribed due to free riders ${ }^{4}$.

In the $\mathrm{UK}^{5}, 88 \%$ of large household appliances is recycled, $26 \%$ of office and communication waste is recycled, and $4 \%$ of entertainment electronics. About $10 \%$ of WEEE was shipped illegally to non-OECD countries.

Landfilling is still practiced, but it is likely that an increasing number of the countries will prohibit landfilling in the future. A large part of the equipment will be shipped to other OECD countries for high-level recovery.

Amounts exported/imported

Countries are forced by the EU legislation to process generated WEEE as much as possible within the national borders or within the region/OECD. Switzerland, for example, is no longer issuing permits for the export of WEEE.

As long as data from the competent authorities (Basel Convention Secretariat, European Commission, EEA) on WEEE import and export are lacking, a first rough estimation can be made of the amount of WEEE that the $\mathrm{EU}$ is probably exporting to Asia and other regions like Africa and Eastern Europe.

\footnotetext{
${ }^{4}$ Dutch Ministry of Housing, Spatial Planning and Environment, VROM Inspectorate, 2005, 2006

${ }^{5}$ www.wasteonline.org.uk
}

It can be assumed that free riders are still responsible for a volume of $10-20 \%$ illegal export of total WEEE to nonOECD countries, and that part of the computer, cell phone, and TV equipment (say $30 \%$ of categories 3 and 4 of WEEE) is exported legally for reuse in developing countries. Thus, a total amount of $0.15 \times 7,005,000$ (free riders part) $+0.3 \times(0.2+0.2) \times 7,005,000$ (tons cat $3+4$ WEEE) $=1.9 \mathrm{mln}$ tons of WEEE and related functioning (remanufactured) equipment is leaving the EU annually for non-OECD countries.

A control program of the Dutch Dutch Ministry of Housing, Spatial Planning and the Environment Inspectorate on illegal trans-boundary WEEE streams leaving the Netherlands, has shown that a total amount of 1,000 tons of WEEE (mainly TVs and refrigerators) was illegally transported, of which $43 \%$ was destined for China/Hong Kong, $7 \%$ for other Asian countries (Malaysia, Pakistan, etc.), $28 \%$ for West Africa (Ghana, Nigeria, etc.), 7\% for Eastern Europe (Romania and Poland), and 10\% for the Middle East and North Africa (Egypt, Jordan, Iran, and Turkey). If this outcome is translated into an EU figure on the basis of population ratios, it would mean that 30,000 tons of these types of WEEE or roughly $10 \%$ is exported illegally. This corresponds reasonably well with our previous assumption of the contribution of free riders (10-20\%).

Used TVs and PCs are often exported from the Netherlands to Eastern Europe, Africa, and probably to India and China. Second-hand copiers are sold to Eastern Europe and Africa [49].

Excluding import quantities between member states of the EU, the total import of WEEE into the EU is not likely to be of quantitative significance.

North America

Generated volume of WEEE

As no legal federal obligation exists in the USA to collect and reuse WEEE, there is less incentive to collect accurate data on the processing of these waste streams. Therefore, obtaining reliable data for the USA is even more difficult than for Europe. The analysis is based on information available in policy documents ${ }^{6}$ and data from the United States Environmental Protection Agency (EPA), such as a pilot study carried out in 2002 in Region 3 of EPA on the prevention of landfilling with WEEE by recycling ${ }^{7}$ and a survey published in 2007 [47], as well as work done by Kahhat et al. [22].From these documents, a rough estimation has been derived of the volumes of the four WEEE categories. These values have a relatively large uncertainty, which applies less to the total amount of discarded WEEE.

\footnotetext{
${ }^{6}$ The Voluntary National Electronics Policy Action Plan, 2005

${ }^{7}$ www.epa.gov/reg3wcmd/pdg/eCyclingExecutiveSummary.pdf.
} 
According to EPA, in 1997 more than $3.2 \mathrm{mln}$ tons of ewaste ended up in US landfills. EPA estimated that $2 \mathrm{mln}$ tons of used computers and TVs were discarded in 2000.

EPA estimated for 2003 that $2-5 \%$ of the municipal solid waste (approx. $236 \mathrm{mln}$ tons annually) consisted of WEEE. This means a yearly WEEE supply of 4-10 mln tons. Until 2000 , this amount was mainly dumped in landfills.

In later documents ${ }^{8}$, the following data are provided under the category "selected consumer electronics" in the municipal waste stream; Table 5

However, more recent data [47] estimate the generated waste quantities of home computers, monitors, TVs, printers, and cell phones in 2005 at 1.9 mln tons, of which $18 \%$ is recycled or exported and $80 \%$ landfilled or incinerated. Incineration involves only $3 \%$ of this fraction. On the basis of these data, it is estimated that in 2005, $2 \mathrm{mln}$ tons of computers, TVs, monitors, etc., were generated.

Based on the information above, it is estimated that the total supply of WEEE in the USA amounted to at least $6.6 \mathrm{mln}$ tons in 2005 , or $22 \mathrm{~kg} / \mathrm{inh}$./year. For this estimation, it is assumed, also looking at the more detailed EU data available, that computers and TVs comprise not more than about $30 \%$ of total WEEE in the USA. According to the Basel Action Network [1], in 1998, WEEE waste generated in the USA amounted to 5-7 $\mathrm{mln}$ tons. Assuming a steady growth of that amount, our estimated figure for the USA of $22 \mathrm{~kg} /$ capita in 2005 may be too low.

The contribution of the four WEEE categories is roughly (yearly estimates):

$60 \%$ is large household appliances (fridges and washing machines; $13.2 \mathrm{~kg} / \mathrm{inh}$.)

$8 \%$ small household appliances (vacuum cleaners and toasters; $1.7 \mathrm{~kg} / \mathrm{inh}$ )

$16 \%$ office and communication waste (computers and cell phones; $3.5 \mathrm{~kg} / \mathrm{inh}$.)

$16 \%$ entertainment electronics (radios, TVs, and stereos; $3.5 \mathrm{~kg} / \mathrm{inh}$.)

Amount recycled and landfilled in the region

Until 2000, most of the WEEE, including some 50 million computers and TVs, was landfilled or incinerated in the USA. Only $11 \%$ of discarded computers were recycled in 1999. In 2003, this was not more than $12 \%$. Landfilling is stabilizing in the USA, and the growing volumes are fuelling a search for other routes such as export. As said, about $80 \%$ of the national amounts of WEEE are estimated to be landfilled or incinerated in recent years. This is the result of voluntary federal programs and

\footnotetext{
${ }^{8}$ EPA: Municipal Solid Waste Generation, Recycling, and Disposal in the United States; Facts and Figures for 2003
}

the more strict legal requirements in states such as California. This value is likely to decrease slowly over the next decade. It is uncertain whether strong protests by Nongovernmental Organizations in view of the negative environmental effects in developing countries as well as media attention, which is already arising, will cause this export to diminish in the future.

Amounts exported/imported

Contrary to the situation in the EU, the USA has no political objections to exporting to non-OECD countries, which has resulted in a growing export of the total supply of either still functioning equipment or equipment that will be dismantled, incinerated, and landfilled in developing countries. For the EU, a total export portion of approximately $25 \%$ of total WEEE was estimated.

On the basis of an interview with a trader in 2002 (Exported Harm, The High-Tech Trashing of Asia), the Basel Action Network and Silicon Valley Toxics Coalition estimated that $80 \%$ of what is labeled as recycled computers and TVs is exported from the USA to Asia, of which $90 \%$ is estimated to go to China. In 2005, the export of category 3 and 4 e-waste from the USA may, therefore, have been around $16 \%$, due to the large remaining role of landfilling, but this value may rise to similar or higher levels as for the EU after 2010.

For the category 1 WEEE stream, possibly higher export levels occur in view of the higher metal content which is in great demand in China.

On the basis of these considerations, the total amount of US e-waste exported is estimated at 0.2 (average of $20 \%$ is exported $) \times 6.6(\mathrm{mln}$ tons of total WEEE supply $)=$ $1.3 \mathrm{mln}$ tons per year. This value is somewhat lower than the export of WEEE from the EU.

No figures have yet been found on the import of WEEE, but it is not likely that such amounts are of substantial significance compared to the export figures.

Data for Canada have not been included. Roughly speaking, including Canada would increase the figures by $10 \%$.

Asia

Generated volume of WEEE

The situation in Asia is diverse. Japan, with an even higher ICT expenditure per inhabitant than the USA ${ }^{9}$ (US $\$ 3,256$ in Japan and US $\$ 2,924$ in the USA in 2001), contrasts with Malaysia (US \$262), Thailand (US \$76), China (US \$53), and India (US \$19). However, China and India belong to the countries with the fastest PC growth in the world and are dump sites for e-waste residues.

Against this background, most attention will be given to China and India. The legal situation in Japan is, to a large extent, comparable to the situation in the $\mathrm{EU}[22,51]$.

\footnotetext{
${ }^{9}$ World Bank, World Development Indicators Online
} 
Table 5 US EPA estimates of selected consumer electronics in municipal waste steams

a does not include converting/
fabrication of scrap

fabrication of scrap

\section{Japan}

On the basis of its population and by using ICT expenditure as reference point, the total WEEE production in Japan can be estimated through a comparison with the USA. This amount can be estimated as follows: 3256/2924 (ICT expenditure ratio Japan/USA) $\times 127 / 298$ (population ratio Japan/USA $) \times 6.6 \mathrm{mln}$ tons $($ WEEE production USA $)=$ $3.1 \mathrm{mln}$ tons or $24 \mathrm{~kg} / \mathrm{inh}$./year.

Japan has enforced obligations on retailers to collect and transfer discarded EEE from consumers, as well as a compulsory system since 2001 of recycling personal computers, including recycling fees [55]. To estimate the contribution of the four WEEE categories in Japan, the average values of those developed for the EU and the USA are applied (yearly averages):

$55 \%$ is large household appliances (fridges and washing machines; $13.2 \mathrm{~kg} /$ inh.)

9\% small household appliances (vacuum cleaners and toasters; $2.2 \mathrm{~kg} /$ inh.)

$18 \%$ office and communication waste (computers and cell phones; $4.3 \mathrm{~kg} / \mathrm{inh}$.)

$18 \%$ entertainment electronics (radios, TVs, and stereos; $4.3 \mathrm{~kg} / \mathrm{inh}$.

It is likely that most of it stays in Japan [39] with the remainder exported to China and India, as only a small fraction ends up in, e.g.,Lagos and Nigeria. According to an article in National Geographic News ${ }^{10}, 45 \%$ of the WEEE coming into Lagos originates from the USA, $45 \%$ from the EU, and 10\% from Japan.

China

A similar formula as used for WEEE production in Japan can be used to approximate WEEE production in China. This results in: 53/1924 (ICT expenditure ratio China/ USA) $\times 1314 / 298$ (population ratio China/USA) $\times 6.6 \mathrm{mln}$ tons $=0.53 \mathrm{mln}$ tons WEEE per year. However, Yang et al. [54] have made a more detailed study of waste production in China and estimate total WEEE generation for 2003 at a much higher amount of $1.76 \mathrm{mln}$ tons and for 2005 already at $3.1 \mathrm{mln}$ tons, values that do not include imports. The rapid increase is the combined effect of increasing sales numbers and decreasing medium lifetimes. In 2003, about half of this WEEE is caused by obsolete TV sets.

\footnotetext{
$\overline{10}$ news.nationalgeographic.com/news/2005/11/1108_051108_electronic_waste_2.html
}

For 2005, the following WEEE production data can be calculated using data from Yang et al. [54]:

large household appliances (fridges, washing machines, and aircons; $2.0 \mathrm{~kg} / \mathrm{inh}$.)

small household appliances (vacuum cleaners and toasters; estimation; $0.2 \mathrm{~kg} / \mathrm{inh}$.)

office and communication waste (computers; $0.3 \mathrm{~kg} / \mathrm{inh}$.) entertainment electronics (TVs; $0.8 \mathrm{~kg} /$ inh.)

India

For India, the WEEE approximation results in the following amount: $19 / 1924 \times 1095 / 298 \times 6.6 \mathrm{mln}$ tons $=$ $0.24 \mathrm{mln}$ tons per year.

In the eWaste Guide ${ }^{11}$, a value of $0.15 \mathrm{mln}$ tons generated is given for India for 2002. As in China, however, fast growth may result in nearly a doubling in three years' time. Nearly $90 \%$ of this WEEE comes from large household appliances (42.1\%), information and communication technology equipment (33.9\%), and consumer electronics (13.7\%). Top cities in WEEE generation are Mumbai, Delhi, Bangalore, and Chennai. Total e-waste generated for 2005 is $0.22 \mathrm{~kg} /$ capita, considerably less than the $3.3 \mathrm{~kg} /$ capita calculated for China. To get some idea, we can compare the estimated number of scrap PCs in India in 2005 calculated by Streicher-Porte et al. [43] to be 500,000 units. In China, the corresponding number was $9.8 \mathrm{mln}$ units, which is nearly 20 times higher. This confirms the estimated large difference in WEEE generation between these two countries.

Amounts recycled and landfilled in the region

All WEEE produced in China and India probably is processed domestically.

The recycling system is highly unorganized and mainly takes place in the informal economy. In cities like Beijing, there are large second-hand markets. After sorting and dismantling e-waste, it is sent from Beijing to Southeast China [54], mainly to Guang Dong and Zhe Jiang provinces, where the actual refining and metal recovery operations take place ${ }^{12}$.

Amounts exported/imported

Japan

Most exported WEEE from Japan ends up in China and India because of geographical and cost considerations. As

\footnotetext{
${ }^{11}$ www.e-waste.in/weee_basics

12 www.e-waste.ch/case_study_china
} 
Japan is a nation of islands, it will have a higher incentive than the USA to avoid landfilling. Therefore, it is assumed that landfilling will be practiced at a level between that of the USA and of the EU, and that a comparable level of export as found for the EU will be realized, such as $20-25 \%$. However, data supporting this assumption have not yet been found. On the basis of an assumed export value of $20 \%$ of the WEEE supply, generated export from Japan to non-OECD countries may be as much as $0.2 \times 3.1 \mathrm{mln}$ tons $=0.62 \mathrm{mln}$ tons, about half of the quantity exported by the USA. It may be assumed that about $60 \%$ goes to China, $30 \%$ to India, and $10 \%$ to Africa. Import will not be an important factor.

China

For China, export is as yet of no significance. Figures for the total amount of WEEE imported are difficult to obtain. Importing e-waste is formally prohibited ${ }^{13}$, but enforcement is still weak. However, Chinese requirements have been upgraded recently and transports not meeting standards are returned regularly. An approximation of the total import in China may tentatively be derived from the earlier estimations. To produce this figure, estimations have to be made of the total amounts imported from the USA and the EU, in addition to the import from Japan. As China has been very active in attracting WEEE as a source of raw materials and economic growth - and until recently neglecting serious environmental concerns - it will have higher imports from Europe and the USA than India. This active approach is reflected in China's offices in major global seaports such as Rotterdam. In this phase, it is assumed that $70 \%$ of USA WEEE export ends up in China ${ }^{14}, 20 \%$ in India, and $10 \%$ in Africa. Export to Africa is likely to increase in the coming years as requirements are becoming more stringent in Asia. For the EU, it is assumed that $20 \%$ of WEEE export ends up in West Africa and 20\% in Eastern Europe and North Africa. The remainder $60 \%$ probably goes to Asia, of which, $65 \%$ may go to China and $35 \%$ to India, neglecting, for the time being, export to smaller other Asian countries.

The following amounts result for import into China:

$\begin{array}{lll}\text { Imported from EU } & 0.6 \times 0.65 \times 1.9 \mathrm{mln} \text { tons } & =0.74 \mathrm{mln} \text { tons } \\ \text { Imported from USA } & 0.7 \times 1.3 \mathrm{mln} \text { tons } & =0.91 \mathrm{mln} \text { tons } \\ \text { Imported from Japan } & 0.6 \times 0.62 \mathrm{mln} \text { tons } & =0.37 \mathrm{mln} \text { tons } \\ & \end{array}$

According to Greenpeace China ${ }^{15}$, a concentration of ewaste dismantling sites can be found throughout the Guiyi area since 1995 . In 2002, it was estimated that 100,000

\footnotetext{
${ }^{13}$ Regulation on Waste Imports for Environmental Protection and Management (Interim), SEPA, 1996

${ }^{14}$ Xinhua News [53], http://news.xinhuanet.com/fortune/2005-09/03/ content_3437772.htm (in Chinese)

${ }^{15}$ BAN report, Exporting Harm [1], p. 15
}

workers were employed in this area in the e-waste sector, causing very serious pollution problems. According to the Xinhua News [53], 30,000-40,000 workers are involved in WEEE treatment in Guiyi, treating over $1 \mathrm{mln}$ tons of WEEE annually. As this reflects only part of the reuse activity in China, the above estimate of $2.02 \mathrm{mln}$ tons of imported WEEE is in line with this source. E-waste in this area is reported to be mainly of American origin, while, to a lesser degree, e-waste came from Japan, South Korea, and Europe. These indications are not too different from the estimates given above.

\section{India}

Like China, India has formally prohibited the import of e-waste but is not very strict about enforcing this policy. About $50 \%$ of the computers sold in India are products from the second-hand market. The market for e-waste is less concentrated than in China and spread across many different places, each handling a different aspect of recycling. All work is done with bare hands and by women and children. ${ }^{16}$

On the same basis as developed for China, the total amount imported in India can be estimated as follows:

$\begin{array}{lll}\text { Imported from EU } & 0.6 \times 0.35 \times 1.9 \mathrm{mln} \text { tons } & =0.40 \mathrm{mln} \text { tons } \\ \text { Imported from USA } & 0.2 \times 1.3 \mathrm{mln} \text { tons } & =0.26 \mathrm{mln} \text { tons } \\ \text { Imported from Japan } & 0.3 \times 0.62 \mathrm{mln} \text { tons } & =0.19 \mathrm{mln} \text { tons } \\ & & 0.85 \mathrm{mln} \text { tons }\end{array}$

\section{West Africa}

Finally, an estimation for West Africa, based on the previous assumptions, produces the following figures for 2005:

$\begin{array}{lll}\text { Imported from EU } & 0.2 \times 1.9 \mathrm{mln} \text { tons } & =0.38 \mathrm{mln} \text { tons } \\ \text { Imported from USA } & 0.1 \times 1.3 \mathrm{mln} \text { tons } & =0.13 \mathrm{mln} \text { tons } \\ \text { Imported from Japan } & 0.1 \times 0.62 \mathrm{mln} \text { tons } & =0.06 \mathrm{mln} \text { tons } \\ & \end{array}$

Estimations for the year 2010

Estimations for WEEE processing and recovery for the year 2010 are based on a number of assumptions, which are presented below.

EU-25

Based on sources such as Huisman et al. [21], it is assumed that e-waste generation increases by $5 \%$ each year. In consequence, the total amount generated will increase from $7 \mathrm{mln}$ tons in 2005 to $8.94 \mathrm{mln}$ tons in 2010 .

It is, furthermore, assumed that as a result of stricter legislation and better enforcement, illegal export will diminish from $15 \%$ to $10 \%$, resulting in a quantity of $0.89 \mathrm{mln}$ tons in 2010.

\footnotetext{
$\overline{16}$ eWaste Guide: www.e-waste.in/weee basics
} 
Due to regional EPR programs, legal export will diminish from $30 \%$ to $20 \%$, resulting in $(2.2 \times(0.2+0.2) \times$ $8.92=0.72 \mathrm{mln}$ tons in 2010 . The total export from EU to non-OECD countries will come to $1.61 \mathrm{mln}$ tons.

Recycling will consequently increase to $66 \%$ of the waste stream, resulting in $5.9 \mathrm{mln}$ tons in 2010 .

USA

Based on values for 2003-2005 from EPA [47], e-waste generation of categories 3 and 4 increases by $5 \%$ per year:

The total amount generated will then increase from $6.6 \mathrm{mln}$ tons to $8.4 \mathrm{mln}$ tons.

It is assumed that recovery will increase from about $15 \%$ to $25 \%$ in 2010 due to programs at state level, resulting in $2.1 \mathrm{mln}$ tons. However, $80 \%$ is exported (1.68 mln tons), resulting in $2.1-1.68=0.42 \mathrm{mln}$ tons recycled.

Exports of recovered materials after recycling are estimated at $1.7 \mathrm{mln}$ tons. It is not yet known what will happen with the accumulating amount of stored devices, which will in the future either be dumped or exported for a good price. The latter is the most likely scenario as market forces are the main driver for actions in the USA. Therefore, an extra export flow can be expected to emerge at the cost of landfilling, storage and incineration, with a magnitude of approximately $10 \%$ of the potential landfilling/incineration flow.

This will result in 8.4-1.7-0.42 $=6.3 \times 10 \%=0.63 \mathrm{mln}$ tons extra export. Total export will on the basis of these assumptions amount to $0.63+1.7=2.3 \mathrm{mln}$ tons in 2010 .

Japan

Assuming similar growth figures as for the EU and the USA, WEEE generation will increase by $5 \%$ annually, resulting in an increase from 3.1 to $3.96 \mathrm{mln}$ tons [54].

Assuming a growth of collected e-waste from $60-80 \%$ (in South Korea, 70\% recollection was achieved in 2006 [22]), of which $10 \%$ goes to landfills/incinerators, this results in a recycled amount of $0.7 \times 3.96=2.77 \mathrm{mln}$ tons.

In $2005,20 \%$ of e-waste generated was exported. It is likely that this amount will slowly diminish. A value of $15 \%$ is applied, resulting in an export flow of $0.59 \mathrm{mln}$ tons.

China

Yang et al. [54] have estimated growth figures for ewaste generation in China until 2010. Their projections show a stabilization of the supply of obsolete refrigerators and washing machines but a steady growth of PCs and aircons. The result is a projected e-waste growth from 3.1 to $5.7 \mathrm{mln}$ tons in 2010 .

Assuming a similar distribution of export flows from OECD countries as used in 2005, the following contributions to import can be estimated:

From USA: $2.3 \times 0.7=1.61 \mathrm{mln}$ tons

From EU: $1.6 \times 0.39=0.62$
From Japan: $0.59 \times 0.61=0.36$

Total import: $2.59 \mathrm{mln}$ tons.

Recycling will slowly move from the informal to the formal market in China, the pace of which depends on the type of government priority given to this sector. It is not unlikely that recycling will increase from $30 \%$ to $50 \%$ in this period.

This would lead to a total amount recycled of $0.5 \times$ $(5.7+2.6)=4.2 \mathrm{mln}$ tons.

India

It may be assumed that e-waste growth in India will be similar to that in China. PC sales data indicate that this sector follows a similar path in both countries. This means that the total quantity of e-waste generated will be at least $0.66 \mathrm{mln}$ tons.

Assuming a similar distribution of export flows from OECD countries as for 2005 , the following contributions to import can be estimated:

From USA: $2.3 \times 0.2=0.46 \mathrm{mln}$ tons

From EU: $1.6 \times 0.21=0.34$

From Japan: $0.59 \times 0.29=0.17$

Total import: $0.97 \mathrm{mln}$ tons.

Recovery will gradually increase in India, but probably not as fast as in China. It is assumed that recycling will increase from $30 \%$ to $40 \%$ in this period.

This would lead to a total amount recovered of $0.4 \times$ $(0.7+1.0)=0.68 \mathrm{mln}$ tons .

West Africa

Assuming a similar distribution of export flows from OECD countries as for 2005 , the following contributions to import can be estimated:

From USA: $2.3 \times 0.1=0.23 \mathrm{mln}$ tons

From EU: $1.6 \times 0.2=0.32$

From Japan: $0.59 \times 0.1=0.06$

Total import: $0.61 \mathrm{mln}$ tons.

Recycling will slowly improve in West Africa but probably not as fast as in China. It is assumed that recycling will increase from 30 to $35 \%$ in this period.

This would lead to a total amount recycled of $0.35 \times$ $0.61=0.21 \mathrm{mln}$ tons.

The following table provides a summary of the data discussed.

Table 6

\section{Appendix 2. WARM approach: a simple tool for decision making}

To help equipment manufacturers, in particular SMEs, identify the profitable options that high-level recovery 
Table 6 Global WEEE production, disposal, recovery and import/export estimates ${ }^{\mathrm{a}}(2010)$

\begin{tabular}{|c|c|c|c|c|c|}
\hline $\begin{array}{l}\text { Country/ } \\
\text { region }\end{array}$ & $\begin{array}{l}\text { Annual household } \\
\text { production in mln tons }\end{array}$ & $\begin{array}{l}\text { Landfilling, storage and } \\
\text { incineration in mln tons }\end{array}$ & $\begin{array}{l}\text { Domestic recovery } \\
\text { in } \mathrm{mln} \text { tons } \mathrm{s}^{\mathrm{b}}\end{array}$ & $\begin{array}{l}\text { Annual export in } \\
\text { mln tons }\end{array}$ & $\begin{array}{l}\text { Annual import in } \\
\text { mln tons }\end{array}$ \\
\hline USA & 8.4 & 5.7 & 0.42 & 2.3 & - \\
\hline EU-25 & 8.9 & 1.4 & $5.9^{\mathrm{c}}$ & 1.6 & - \\
\hline Japan & 4.0 & 0.6 & 2.8 & 0.59 & - \\
\hline China & 5.7 & 4.1 & 4.2 & - & 2.6 \\
\hline India & 0.66 & 0.95 & 0.68 & - & 0.97 \\
\hline $\begin{array}{l}\text { West } \\
\text { Africa }\end{array}$ & 0.07 & 0.47 & 0.21 & - & 0.61 \\
\hline
\end{tabular}

${ }^{\text {a }}$ From the recovered stream, part is disposed within the country/region (see estimate), part is exported to the developing world (see estimate), and the remainder is reused directly or through different types of processing like refurbishment and remanufacturing

${ }^{b}$ It is assumed that $30 \%$ of the waste generated and imported is recycled in China, India, and West Africa

${ }^{\mathrm{c}}$ It is assumed that $66 \%$ of the waste generated is recycled in the EU-25

offers, a method has been developed which we call the "WARM ${ }^{17}$ approach". This approach was developed in an applied research program involving a series of pilot projects, studies, and many interviews. It involved manufacturers of quite different types of equipment as well as businesses offering services in remanufacturing and refurbishment. The focus was on SMEs or smaller units of larger consortia. Nevertheless, much use was made of the experience of larger companies, such as Océ and Flextronics. These firms were quite eager to share their knowledge in this field. In total, some 15 manufacturers were involved in practical pilot studies, and some 25 who already practice remanufacturing were used as reference, or as "critical" respondents in interviews and workshops. The 15 firms mentioned included manufacturers of medical and healthcare equipment (Focal Instruments and Moving People), beverage dispensers (Coffee3), air separation equipment (Norton Filters), and office equipment (a Flextronics production and research location).

The WARM approach aims to assess the profitable highlevel recovery options that exist, as well as the possible constraints and efficient solutions to deal with those constraints. These solutions can be of a technical but also commercial or logistical nature. The objective is a method particularly suited to smaller equipment manufacturers, implying a simple and time-efficient approach. That approach is therefore, step-by-step:

1. a quick analysis with few but highly relevant questions: could it be interesting at all;

2. an in-depth analysis of parts and costs available for reuse, using with a fast and structured model; and

3. a checklist of specific actions to be taken to implement reuse in a low-cost and efficient manner.

\footnotetext{
${ }^{17}$ WARM is an acronym for Waste and Recovery Management.
}

Figure 6 shows the framework as we present it to the manufacturer. The first step is fairly qualitative, bringing into view the possible complexity and the problems in the various areas of the whole framework that need to be addressed. It is based on the "subjectively perceived extent" of options and problems in the three main areas of the operations that have to be adapted, as perceived by people within the company (though critically reviewed by the consultant). This is performed rapidly, in just a few hours. The result is a diagram as shown in Fig. 7. A score of over 50 indicates a positive view of the possibilities, below 50 indicates a less attractive situation. This step also makes the company aware of the actual possibilities that reuse offers in their case. Since it costs so little time, the threshold to "discuss it just once" is low. Even if the score is below 50, some companies continue to consider the options, possibly returning to it later. Problems are often solved simply, just by introducing an innovative procedure alone or minor adaptations to the design. In the second step, the critical factors determining the feasibility of reuse are identified for all parts and modules. This concerns:

- technical aspects, expected wear, and remaining lifetime

- testing method and guarantees that have to be given

- costs for refurbishment and remanufacturing against remaining value, using "activity-based costing"

- market options

- specific company priorities and ambitions.

Based on these results, the parts and modules to be reused are selected. In some of the cases of our research program, we observed that up to $90 \%$ of parts could be are reused. Nevertheless, for practical reasons, companies were advised to start with a limited number of high-value parts such as electrical motors, the main frames of the equipment, 
and so on. Refurbishment is not very complicated and redesign is not directly required, meaning, that one can start with the parts in their present form.

The next step is the implementation, for which much knowledge is already available, such as for reverse logistics and testing methodology. In the Netherlands, a platform has been set up to make such knowledge easily available to companies considering introducing closed-loop reuse.

\section{References}

1. Basel Action Network, Silicon Valley Toxicity (2002) Exporting harms, http://www.svtc.org/cleancc/pubs/technotrash.pdf

2. van Berkel R (2007) Eco-efficiency in primary metals production: context, perspectives and methods. Resour Conserv Recycl 51 (3):511-540

3. Bloemhof-Ruwaard JB, Van Wassenhove LN, Gabel HL, Weaver PM (1996) Environmental Life-cycle optimization model for the European pulp and paper industry. Omega 24-6:615-629

4. Chung SW, Yoshida F (2006) Transition from the producer deposit refund system to the Extended Producer Responsibility regime in Korea: current state and policy challenges regarding mainly consumer appliances. Working paper, Graduate School of Economics and Business Administration, Hokkaido University, Sapporo, Japan

5. Comperen A (2006) personal communication, Director Ace Reuse Technology

6. Company information (2006) private communication Van Knippenberg Océ Asset Recovery, Further internal reports and websites Flextronics, Xerox, Catterpillar, Siemens, Coca Cola in framework WARM development project (Annex 2)

7. Cooper T, Evans S (2000) Products to services, Sheffield Hallam University, centre for sustainable consumption, technical paper

8. Di Bucchianico A, Figarella Gomez TR, Hulsken G, Jansen MH, Wynn HP (2004) A multi-scale approach to functional signature analysis for product end-of-life management. Qual Reliab Eng Int 20-5:457-467

9. Better Regulation for Growth and Jobs in the European Union (2005) Communication from the Commission to the Council and the European Parliament COM (2005) 97 final, Commission of the European Communities, Brussels, 16 March

10. Eilperin J (2005) Dead electronics going to waste. Washington Post, January, A04

11. Enviros (2002) Potential markets for waste electronic and electrical equipment (WEEE), (http://www.londonremade. com/londonremade/downloadfiles/mkts $\% 20$ for $\% 20$ WEEE $\%$ 20report202.doc.)

12. European Parliament and The Council (2003) Directive 2002/96/ EC of 27 January 2003 on waste electrical and electronic equipment (WEEE), Official Journal of the European Union, 13.2.2003, L 37/24-38

13. Ginsburg J (2001) Manufacturing: once is not enough; more companies are finding profits in "remanufacturing", Business week, April 16

14. Giuntini R, Gaudetten K (2003) Remanufacturing: the next great opportunity for boosting US productivity, Business Horizons, November-December 2003, 41-48

15. Gray C, Charter M (2007) Remanufacturing and product design, report for SEEDA, UK. Center for Sustainable Design, University College for the Creative Arts, Farnham UK

16. Guide D, Van Wassenhove LN (2001) Managing product returns for remanufacturing. Prod Oper Manag 10-2:142-154
17. Hammond D, Beullens P (2007) Closed-loop supply chain network equilibrium under legislation. Eur J Oper Res 183 (2):895-908

18. Hischier R, Wager P, Gauglhofer J (2005) Does WEEE recycling make sense from an environmental perspective? Environmental and social impacts of electronic waste recycling. Environ Impact Asses Rev 25(5):525-539

19. Huisman J (2003) The QWERTY/EE concept, quantifying recyclability and eco-efficiency for end-of-life treatment of consumer electronic products, Ph.D. thesis, Technical University Delft

20. Huisman J, Stevels A, Marinelli T, Magalini F (2006) Where did WEEE go wrong in Europe? Practical and academic lessons for the US, Proceedings of the 2006. IEEE International Symposium on Electronics and the Environment, IEEE, 83-88

21. Huisman J, Magalini F, Kuehr R, Maurer C, Ogilvie S, Poll J, Delgado C, Artim E, Szlezak A, Stevels A (2007) 2008 Review of Directive 2002/96 on Waste Electrical and Electronic Equipment. United Nations University, Bonn, 05 August

22. Kahhat R, Kim J, Xu M, Allenby B, Williams E, Zhang P (2008) Exploring e-waste management systems in the United States. Resour Conserv Recycl 52(7):955-964

23. Kerr W, Ryan C (2001) Eco-efficiency gains from remanufacturing: a case study of photocopier remanufacturing at Fuji Xerox Australia. J Clean Prod 9:75-81

24. Krikke H, Bloemhof-Ruwaard J, Van Wassenhove L (2003) Concurrent product and closed-loop supply chain design with an application to refrigerators. Int J Prod Res 41(16):36893719

25. Krikke HR, le Blanc HM, van de Velde S (2004) Product modularity and the design of closed-loop supply chains. Calif Manage Rev 46(2):23-39

26. Krikke HR, Zuidwijk (2008) Disposition choices based on energy footprints instead of recovery quota, Applying Pareto frontiers to analyze the effectiveness of extended producer responsibility CentER discussion paper, 2008-74, submitted to POM; http:// center.uvt.nl/pub/dp2008.html

27. Lifset R, Lombardi R (1997) Who should pay? And why? Some thoughts and the conceptual foundations for the assignment of Extended Producer Responsibility, Proceedings of OECD International Workshop on EPR, Ottawa, Canada

28. Lohse J, Winteler S, Wulf-Schnabel J (1998) Collection targets for waste from electric and electronic equipment (WEEE). DGXI of the Commission of the European Communities, Brussels

29. Lund RT (1996) The remanufacturing industry, hidden giant. Boston University

30. Mayers K (2001) An investigation of the implications and effectiveness of Producer Responsibility for the Disposal of WEEE, Ph.D. thesis, September, Brunel University, UK

31. Nathan S (2007) Environmental impact of JIT, effects of altered supplier transportation, White paper, wwww.esm.ucsb.edu

32. Nnorom IC, Osibanjo O (2008) Overview of e-waste management practices and legislations, and their poor applications in the developing countries. Resour Conserv Recycl 52:843-858

33. Ogushi Y, Kandlihar M (2007) Assessing extended producer responsibility laws in Japan. Environ Sci Technol 41-13:45024508

34. OECD (2001) Proceedings of OECD seminar on extended producer responsibility, 13-14 December, Paris, France

35. Quariguasi Frota Neto J, Bloemhof-Ruwaard JM, van Nunen JAEE, van Heck HGWM (2008) Designing and evaluating sustainable logistic networks. Int J Prod Econ 111-2:195208

36. Quariguasi Frota Neto J, Walther G, Bloemhof J, van Nunen JAEE, Spengler Th (2009) A methodology for assessing ecoefficiency in logistics networks. Euro Journ Op Res 193(3):670 682 
37. Rubin J, Tal B (2008) Will soaring transport costs reverse globalization?. CIBC World Markets Inc., StrategEcon, May 27, pp. 4-7

38. Savage M, Ogilvie S, Slezak J (2006) Implementation of waste electric and electronic equipment directive in EU 25, IPTS, European Commission Joint Research Centre, Technical Report Series EUR 22231 EN, ISBN 92-79-01926-0

39. Schwarzer S, De Bono A, Giuliani G, Kluser S, Peduzzi P (2005) Ewaste, the hidden side of IT equipment's manufacturing and use. http://www.grid.unep.ch/product/publication/download/ew ewaste. pdf

40. Sinha-Khetriwal D, Kraeuchi P, Schwaninger M (2005) A comparison of electronic waste recycling in Switzerland and in India. Environmental and social impacts of electronic waste recycling. Environ Impact Asses Rev 25(5):492-504

41. Sinha-Khetriwal D, Kraeuchi P, Widmer R (2008) Producer responsibility for e-waste management: key issues for consideration - Learning from the Swiss experience. Journal of Environmental Management, in press (www.sciencedirect.com/science/ article/B6WJ7-4RFD6DN-1/2/cad753c6fa2ea78

42. Steinhilper R (1998) Remanufacturing, the ultimate form of recycling, Fraunhofer IRB Verlag, Stuttgart, technical report

43. Streicher-Porte M, Widmer R, Jain A, Bader H-P, Scheidegger R, Kytzia S (2005) Key drivers of the e-waste recycling system: assessing and modelling e-waste processing in the informal sector in Delhi. Environ Impact Asses Rev 25:472-491

44. SwedWatch (2009) Out of control, e-waste trade flows from the EU to developing countries, www.sedwatch.org

45. Thiery M, Salomon M, van Nunen J, van Wassenhove L (1995) Strategic issues in product recovery management. Calif Manage Rev 37(2):114-135
46. TRI (2007) The Remanufacturing Institute USA, reports on their site: http://www.reman.org/ and Remanufacturing Industry Council International (RICI) http://www.remancentral.com/

47. US EPA (2007) Management of electronic waste in the United States: approach two. EPA530-R-07-004b (http://www.epa.gov/ recycling/manage/htm)

48. Van Wassenhove LN, Chan P, Narayan P (2004) The WEEE challenge. INSEAD Case Study, Fontainebleau, France., retrieved from www.insead.edu, last visited June 2007

49. VROM inspectie (2006) Handhaving afgedankte electronica 2005; www.vrom.nl/waste

50. Walter G, Spengler Th (2005) Impact of the WEEE-directive on reverse logistics in Germany. Int J Phys Distrib Logist Manage 35 (5):337-361

51. Widmer R, Oswald-Krapf H, Sinha-Khetriwal D, Schnellmann M, Boni H (2005) Global perspectives on e-waste. Environmental and social impacts of electronic waste recycling. Environ Impact Asses Rev 25(5):436-458

52. Wright S, Jahanshahi S, Jorgensen F, Brennan D (2002) 'Is metal recycling sustainable?', Proceedings of the international conference on sustainable processing of minerals, green processing 2002 Australian Institute of Mining and Metallurgy, Cairns, Qld, Australia

53. Xinhua News (2005) http://news.xinhuanet.com/fortune/2005-09/ 03/content_3437772.htm (in Chinese)

54. Yang J, Lu B, Xu C (2007) WEEE flow and mitigating measures in China. Waste Manag 28:1589-1597

55. Yoshida A, Tasaki T, Terazono A (2007) Material flow of used PCs in Japan, Proceedings of the 2007 IEEE International Symposium on Electronics and the Environment, IEEE, 46-51 